Supporting Information for

\title{
Sulfanylmethyldimethylaminopyridine as a Useful Thiol Additive for Ligation Chemistry in Peptide/Protein Synthesis
}

\author{
Kento Ohkawachi, ${ }^{\dagger}$ Daishiro Kobayashi, ${ }^{\dagger}$ Kyohei Morimoto,${ }^{\dagger}$ Akira Shigenaga ${ }^{\dagger}$ \\ Masaya Denda ${ }^{\dagger}$ Kenzo Yamatsugu, ${ }^{\star}$ Motomu Kanai, ${ }^{\star}$ and Akira Otaka ${ }^{*} \dagger$ \\ $\dagger$ Insutitute of Biomedical Sciences and Graduate School of Pharmaceutical Sciences, Tokushima \\ University, Tokushima 770-8505, Japan. \\ $\$$ Graduate School of Pharmaceutical Sciences, The University of Tokyo, Tokyo 113-0033, Japan. \\ E-mail: \\ aotaka@tokushima-u.ac.jp
}

\section{Contents}

General methods S2

Preparation of 2-sulfanylmethyl-4-dimthylaminopyridine (SMDMAP) and peptides ...................... S4

Optimization of $\mathrm{pH}$ condition for SMDMAP-mediated NCL reaction.................................................. 11

Examination of side reaction at $\varepsilon$-amino group in SMDMAP-mediated NCL reaction.................... S13

Substrate versatility in SMDMAP-mediated NCL reaction.......................................................... S14

Verification of epimerization of C-terminal chiral amino acids during NCL ……........................... S16

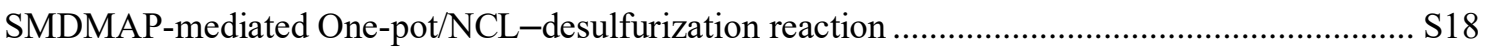

One-pot/N-to-C or C-to-N directed NCLs-desulfurization (Figure 3, 4 original chart).............. S19

One-pot/C-to-N directed NCLs-desulfurization using copper salt............................................. S23

Examination of desulfurization reaction in the presence of copper salts ....................................... S24

Optimization of reaction conditions for SMDMAP-mediated lactam formation............................ S25

Substrate versatility in lactam formation using SMDMAP ......................................................... S26

Verification of epimerization of C-terminal chiral amino acids during lactam formation ............... S28

Comparative study of the additives in lactam formation .............................................................. S29

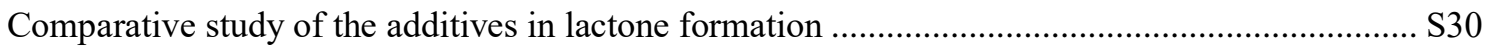

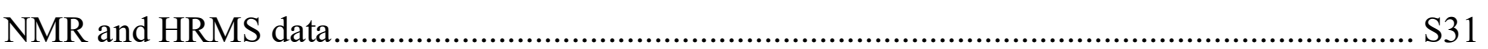

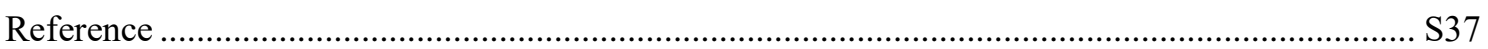




\section{General Methods}

\section{$N M R$}

NMR spectra were recorded using a Bruker AV400N at $400 \mathrm{MHz}$ frequency for ${ }^{1} \mathrm{H}$, and Bruker AV400N at $100 \mathrm{MHz}$ or JEOL JNM-AL300 at $75 \mathrm{MHz}$ frequency for ${ }^{13} \mathrm{C}$ in the stated solvents using tetramethylsilane as an internal standard. Chemical shifts were reported in parts per million (ppm) on the $\delta$ scale from an internal standard (NMR descriptions: s, singlet; d, doublet; dd, double doublet; m, multiplet). Coupling constants, $J$, are reported Hertz.

\section{HPLC and MS}

Mass spectra were recorded on a Waters MICROMASS ${ }^{2} L C T$ PREMIERTM (ESI-TOF). For HPLC separations, a Cosmosil 5C 18 -AR-II analytical column (Nacalai Tesque, $4.6 \times 250 \mathrm{~mm}$, flow rate 1.0 $\mathrm{mL} / \mathrm{min}$ ), a Cosmosil 5C $\mathrm{C}_{18}$-AR-II semi-preparative column (Nacalai Tesque, $10 \times 250 \mathrm{~mm}$, flow rate $3.0 \mathrm{~mL} / \mathrm{min}$ ) and a Cosmosil 5C 18 -AR-II preparative column (Nacalai Tesque, $20 \times 250 \mathrm{~mm}$, flow rate $10.0 \mathrm{~mL} / \mathrm{min}$ ) were employed, and eluting products were detected by UV at $220 \mathrm{~nm}$. A solvent system consisting of $0.1 \%(\mathrm{v} / \mathrm{v})$ TFA aqueous solution (solvent A) and $0.1 \%(\mathrm{v} / \mathrm{v})$ TFA in $\mathrm{MeCN}$ (solvent B) was used for HPLC elution. For LC/MS analysis (Shimadzu, Prominence-I LC-2030, LCMS-2020 equipped with ESI/quadruple mass analyser), a Cosmosil 5C $\mathrm{C}_{18}$-AR-II analytical column (Nacalai tesque, $4.6 \times 250 \mathrm{~mm}$, flow rate $1 \mathrm{~mL} / \mathrm{min}$ ) was employed, and eluting products were detected by $\mathrm{UV}$ at $220 \mathrm{~nm}$ and MS.

\section{Fmoc solid-phase peptide synthesis (Fmoc SPPS)}

Fmoc SPPS was performed according to the following protocol on a various type of C-terminal Fmoc amino acid-incorporated resins. 1) Removal of Fmoc groups was carried out using 20\% (v/v) piperidine in DMF for $10 \mathrm{~min}$ at room temperature. 2) The resin was washed with DMF $(\times 5) .3) \mathrm{A}$ standard Fmoc-protected amino acid (4.0 eq.) was coupled with the aid of $\mathrm{N}, \mathrm{N}$ diisopropylcarbodiimide (DIPCI) (4.0 eq.) and 1-hydroxybenzotriazole monohydrate $\left(\mathrm{HOBt} \cdot \mathrm{H}_{2} \mathrm{O}\right)$ (4.0 eq.), or $N, N$-diisopropylethylamine (DIPEA) (4.0 eq.) and $N, N, N^{\prime}, N^{\prime}$-tetramethyl- $O$ (benzotriazol-1-yl)uronium hexafluoro-phosphate (HBTU, 3.96 eq.) in DMF for $1.5 \mathrm{~h}$ at room temperature. Completion of the coupling reaction was checked by the Kaiser ninhydrin test. The coupling reaction was repeated until the Kaiser test became negative. 4) The resin was washed with DMF $(\times 3)$. A cycle of step 1 to 4 was repeated. Deprotection of acid-labile protecting groups with concomitant release of peptides from a resin was achieved using a cocktail of TFA $/ \mathrm{m}$ cresol/thioanisole/1,2-ethanedithiol/ $\mathrm{H}_{2} \mathrm{O}(80 / 5 / 5 / 5 / 5(\mathrm{v} / \mathrm{v}))(50 \mu \mathrm{L} / 1 \mathrm{mg}$ resin) at room temperature for 1.5-2 h. After the resin was filtered off, cooled diethyl ether $\left(\mathrm{Et}_{2} \mathrm{O}\right)$ was added to the filtrate and the precipitate was collected by centrifugation. The obtained precipitate was washed with cooled $\mathrm{Et}_{2} \mathrm{O}$, 
and purified by preparative HPLC. The following side-chain protected amino acids were employed: $\operatorname{Arg}(\mathrm{Pbf}), \operatorname{Asp}(\mathrm{O} t \mathrm{Bu}), \operatorname{Cys}(\operatorname{Trt}), \operatorname{Glu}(\mathrm{O} t \mathrm{Bu}), \operatorname{His}(\operatorname{Trt}), \operatorname{Lys}(\mathrm{Boc}), \operatorname{Ser}(t \mathrm{Bu}), \operatorname{Tyr}(t \mathrm{Bu})$.

\section{Boc solid-phase peptide synthesis (Boc SPPS) for preparation of peptide thioesters.}

On 4-methylbenzhydrydrylamine (MBHA) resin was coupled Boc-Gly-OH or Boc-Leu-OH as an internal standard amino acid in the presence of DIPCI (4.0 eq.), $\mathrm{HOBt} \cdot \mathrm{H}_{2} \mathrm{O}$ (4.0 eq.) and DIPEA (2.0 eq.) in DMF at room temperature. After $2 \mathrm{~h}$ reaction, removal of Boc group with TFA/anisole/toluene (50:2:48 (v/v)) for $15 \mathrm{~min}$ afforded the H-Gly- or H-Leu-incorporated resin. Reaction of the resulting resin with S-triphenylmethyl mercaptopropionic acid (4.0 eq.) in the presence of DIPCI (4.0 eq.), $\mathrm{HOBt} \cdot \mathrm{H}_{2} \mathrm{O}$ (4.0 eq.) and DIPEA (2.0 eq.) in DMF at room temperature for $2 \mathrm{~h}$, followed by removal of the Trt group by TFA/Et $3 \mathrm{SiH}\left(95: 5\right.$, (v/v)), $10 \mathrm{~min}$ ), gave $\mathrm{HSCH}_{2} \mathrm{CH}_{2} \mathrm{CO}$-functionalized resin. Protected thioester chain was constructed on the thiol-decorated resin by Boc SPPS protocols using the following protocol. 1) Removal of Boc groups was performed with solution of TFA/anisole/toluene $(50 / 5 / 45(\mathrm{v} / \mathrm{v}))$ for $10 \mathrm{~min}$ at room temperature. 2) The resin was washed with toluene $(\times 5)$ followed by DMF $(\times 5) .3$ ) A solution of Boc-protected amino acid (4.0 eq.), DIPCI (4.0 eq.), and $\mathrm{HOBt} \cdot \mathrm{H}_{2} \mathrm{O}$ (4.0 eq.) in DMF was added to the reaction vessel, and the N-terminal amine was then neutralized with DIPEA (2.0 eq.) in situ. The reaction mixture was stirred for $1.5 \mathrm{~h}$ at room temperature. Completion of the coupling reaction was checked by the Kaiser ninhydrin test. 4) The resin was washed with DMF $(\times 5)$ followed by toluene $(\times 5)$. A cycle of step 1 to 4 was repeated. The resulting resin was treated with $1 \mathrm{M}$ trimethylsilyl trifluoromethanesulfonate (TMSOTf)-thioanisole in TFA/m-cresol (100/5 $(\mathrm{v} / \mathrm{v}))\left(50 \mu \mathrm{L} / 1 \mathrm{mg}\right.$ resin) at $4{ }^{\circ} \mathrm{C}$ for $2 \mathrm{~h}$. The resin in the reaction mixture was filtered off and the obtained filtrate was poured into cooled $\mathrm{Et}_{2} \mathrm{O}$ to give a precipitate. The precipitate was collected by centrifugation and washed with cooled $\mathrm{Et}_{2} \mathrm{O}$, and then purified by preparative HPLC. The following side-chain protected amino acids were employed: $\operatorname{Arg}(\mathrm{Mts}), \operatorname{Asp}(\mathrm{OBzl}), \mathrm{Cys}(\mathrm{Acm}), \mathrm{Glu}(\mathrm{OBzl})$, Lys(Cl-Z), Ser(Bzl), Thr(Bzl) Tyr(Br-Z).

\section{Peptide reactions (NCL related reactions, lactam or lactone formation)}

Peptide reaction mixture was stirred at $1250 \mathrm{rpm}$ using BLOCK BATH SHAKER MyBL-100S (FRONT LAB, AS ONE Corporation). These reactions were carried out under argon atmosphere. 
Preparation of 2-sulfanylmethyl-4-dimthylaminopyridine (SMDMAP) and peptides

Synthesis of 4-dimethylamino-2-((tritylthio)methyl)pyridine (4).

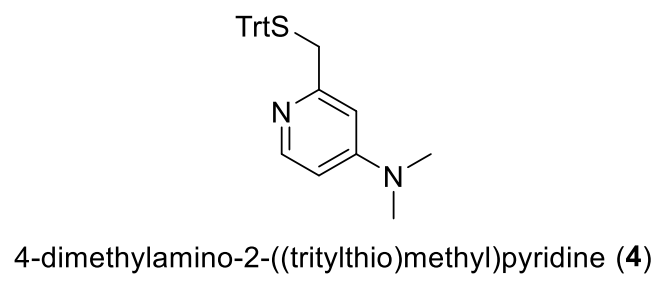

4-Chloro-2-pyridinemethanol (3) (1.2 g, 8.4 mmol, 1.0 eq.), dimethylamine hydrochloride (3.4 g, 42 mmol, 5.0 eq.), $\mathrm{NaOH}(1.6 \mathrm{~g}, 39 \mathrm{mmol}, 4.7$ eq. $)$ and $\mathrm{H}_{2} \mathrm{O}(1.0 \mathrm{~mL})$ were put into a pressure tube, then the apparatus was sealed. The reaction mixture was placed in an oil bath $\left(155^{\circ} \mathrm{C}\right)$ and stirred for $14 \mathrm{~h}$. After being cooled to room temperature, reaction mixture was concentrated in vacuo. The resulting residue was dissolved in $\mathrm{CH}_{2} \mathrm{Cl}_{2} / \mathrm{MeOH}=4 / 1(\mathrm{v} / \mathrm{v})$ and the mixture was treated with $\mathrm{K}_{2} \mathrm{CO}_{3}(2.6 \mathrm{~g})$ for $4 \mathrm{~h}$. After filtration of the reaction, concentration of filtrate under vacuum gave crude 4 dimethylamino-2-pyridinemethanol (1.6 g) as brown oil.

Obtained crude product $(1.6 \mathrm{~g})$ in $\mathrm{CH}_{2} \mathrm{Cl}_{2}(42 \mathrm{~mL})$ was treated with thionyl chloride $(0.91 \mathrm{~mL}, 13$ $\mathrm{mmol}$ ) at room temperature for $15 \mathrm{~h}$. After addition of sat. $\mathrm{K}_{2} \mathrm{CO}_{3}$ aq. to the reaction, resulting mixture was extracted three times with $\mathrm{CH}_{2} \mathrm{Cl}_{2}$. The combined organic layer was washed with brine, dried over $\mathrm{Na}_{2} \mathrm{SO}_{4}$, filtrated and concentrated in vacuo to afford crude 4-dimethylamino-2-chloromethylpyridine $(1.1 \mathrm{~g})$ as brown oil

Reaction of the obtained crude $(1.1 \mathrm{~g})$ with triphenylmethanethiol $(2.6 \mathrm{~g}, 9.4 \mathrm{mmol})$ in the presence of 1,8-diazabicyclo[5.4.0]undec-7-ene $(1.4 \mathrm{~mL}, 9.4 \mathrm{mmol})$ in $\mathrm{CH}_{2} \mathrm{Cl}_{2}(31 \mathrm{~mL})$ at room temperature for $18 \mathrm{~h}$ gave crude reaction mixture. After addition of sat. $\mathrm{K}_{2} \mathrm{CO}_{3}$ aq., resulting mixture was extracted three times with $\mathrm{CH}_{2} \mathrm{Cl}_{2}$ and the combined organic layer was washed with brine, dried over $\mathrm{Na}_{2} \mathrm{SO}_{4}$, filtrated and concentrated in vacuo. The obtained crude material was purified by silica gel column chromatography $\left(\mathrm{CHCl}_{3}\right.$, then $\left.\mathrm{CHCl}_{3} / \mathrm{MeOH}=20 / 1\right)$ to afford $4(1.9 \mathrm{~g}, 4.7 \mathrm{mmol}, 56 \%$ over 3 steps from 1) as a yellow oil. ${ }^{1} \mathrm{H}$ NMR $\left(\mathrm{CDCl}_{3}, 400 \mathrm{MHz}\right): \quad \delta 2.89(\mathrm{~s}, 6 \mathrm{H}), 3.40(\mathrm{~s}, 2 \mathrm{H}), 6.16(\mathrm{~d}, 1 \mathrm{H}, J=$ $2.8 \mathrm{~Hz}), 6.30(\mathrm{dd}, 1 \mathrm{H}, J=2.8 \mathrm{~Hz}$ and $6.0 \mathrm{~Hz}), 7.16-7.21(\mathrm{~m}, 3 \mathrm{H}), 7.25-7.29(\mathrm{~m}, 6 \mathrm{H}), 7.47-7.50(\mathrm{~m}$, $6 \mathrm{H}), 8.11(\mathrm{~d}, 1 \mathrm{H}, J=6.0 \mathrm{~Hz}){ }^{13} \mathrm{C} \mathrm{NMR}\left(\mathrm{CDCl}_{3}, 75 \mathrm{MHz}\right): \quad \delta \quad 39.0,39.2,67.1,105.0,105.6,126.5$, 127.8, 129.6, 144.66 149.26, 154.64, 157.10; HRMS (ESI-TOF) $m / z$ : $[\mathrm{M}+\mathrm{H}]^{+}$Calcd for $\mathrm{C}_{27} \mathrm{H}_{27} \mathrm{~N}_{2} \mathrm{~S}$ 411.1895; Found 411.1891. 


\section{Synthesis of di-SMDMAP·2HCl (5-2HCl).}

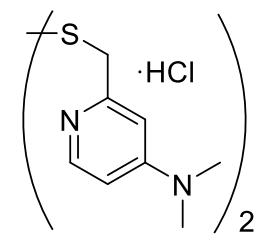

di-SMDMAP. $2 \mathrm{HCl}(\mathbf{5} \cdot 2 \mathrm{HCl})$

S-Protected material 4 (0.55 g, $1.4 \mathrm{mmol}, 1.0$ eq.) was treated with TFA/ $\mathrm{CH}_{2} \mathrm{Cl}_{2}(1: 1,(\mathrm{v} / \mathrm{v}), 24 \mathrm{~mL})$ in the presence of $\mathrm{Et}_{3} \mathrm{SiH}(0.26 \mathrm{~mL}, 1.6 \mathrm{mmol}, 1.2$ eq.). The reaction mixture was stirred at room temperature for $30 \mathrm{~min}$. Concentration of the reaction afforded the crude S-deprotected compounds consisting of thiol and disulfide materials. And this mixture was brought to next oxidation step without further purification. Oxidation of the crude in $\mathrm{DMSO} / \mathrm{H}_{2} \mathrm{O}(1: 4,(\mathrm{v} / \mathrm{v}), 6.0 \mathrm{~mL})$ gave crude disulfide product 5. After adjustment of $\mathrm{pH}$ to $12-13$ with aqueous $\mathrm{NaOH}$, the mixture was extracted five times with $\mathrm{CH}_{2} \mathrm{Cl}_{2}$ and the combined organic layer was dried over $\mathrm{Na}_{2} \mathrm{SO}_{4}$, filtrated and concentrated in vacuo. The resulting residue was dissolved in $4 \mathrm{~N} \mathrm{HCl} / \mathrm{EtOAc}(6.7 \mathrm{~mL})$ with white solid being immediately formed. The forming material was collected by filtration and washed with $\mathrm{Et}_{2} \mathrm{O}$ (crude material $0.12 \mathrm{~g}$ ). Recrystallization of the crude ( $23 \mathrm{mg}, 56 \mu \mathrm{mol})$ from MeOH-EtOAc gave $15 \mathrm{mg}$ (37 $\mu \mathrm{mol}, 28 \%$ over 3 steps from 4$)$ of colorless crystalline solid $(\mathbf{5} \cdot 2 \mathrm{HCl})$.

5.2HCl: mp: decomposition at $197-207^{\circ} \mathrm{C} ;{ }^{1} \mathrm{H}$ NMR $\left(\mathrm{D}_{2} \mathrm{O}, 400 \mathrm{MHz}\right): \delta 3.11(\mathrm{~s}, 6 \mathrm{H}), 3.81(\mathrm{~s}, 2 \mathrm{H})$, $6.55(\mathrm{~d}, 1 \mathrm{H}, J=2.8 \mathrm{~Hz}), 6.69(\mathrm{dd}, 1 \mathrm{H}, J=2.8$ and $7.2 \mathrm{~Hz}), 7.84(\mathrm{~d}, 1 \mathrm{H}, J=7.2 \mathrm{~Hz}) ;{ }^{13} \mathrm{C}$ NMR $\left(\mathrm{D}_{2} \mathrm{O}\right.$, $100 \mathrm{MHz}): \quad \delta \quad 39.15,39.54,105.69,106.89,138.40,148.99,157.30$; HRMS (ESI-TOF) $m / z:[\mathrm{M}+\mathrm{H}]^{+}$ Calcd for $\mathrm{C}_{16} \mathrm{H}_{23} \mathrm{~N}_{4} \mathrm{~S}_{2}$ 335.1359; Found 335.1378. 
Synthesis of thioester peptides (6a-e, 20, S1-6, 22, S13-14).

Synthesis of thioester peptides for the use for intermolecular NCL reactions (6a-e), cyclization reactions (17, S1-S6 and 19) and evaluation of epimerization (S13-S16).

Title thioester peptides were synthesized by Boc SPPS protocol described in General Procedure.

Peptide for intermolecular NCLs

H-LYRANA-S- $\mathrm{CH}_{2} \mathrm{CH}_{2} \mathrm{CO}-\mathbf{L}-\mathrm{NH}_{2}$ (6a) (14 mg, $11 \mu \mathrm{mol}, 25 \%$ isolated yield): Analytical HPLC conditions: linear gradient of solvent B in solvent A, $5 \%$ to $35 \%$ over 30 min, retention time $=20.3$ min. Preparative HPLC conditions: linear gradient of solvent B in solvent A, $15 \%$ to $25 \%$ over $30 \mathrm{~min}$, retention time $=15.4 \mathrm{~min}$. LCMS $(\mathrm{ESI}-\mathrm{TOF}) \mathrm{m} / \mathrm{z}$ calcd for $[\mathrm{M}+\mathrm{H}]^{+} 907.48$, found 907.55

$\mathrm{H}-\mathbf{L Y R} \boldsymbol{R} \boldsymbol{N} \mathbf{L}-\mathrm{S}-\mathrm{CH}_{2} \mathrm{CH}_{2} \mathrm{CO}-\mathbf{L}-\mathrm{NH}_{2}$ (6b) $(7.0 \mathrm{mg}, 5.4 \mu \mathrm{mol}, 12 \%$ isolated yield): Analytical HPLC conditions: linear gradient of solvent B in solvent A, $5 \%$ to $35 \%$ over 30 min, retention time $=25.5$ min. Preparative HPLC conditions: linear gradient of solvent B in solvent A, 20\% to $30 \%$ over $30 \mathrm{~min}$, retention time $=14.5 \mathrm{~min}$. LCMS (ESI-TOF) $\mathrm{m} / z$ calcd for $[\mathrm{M}+\mathrm{H}]^{+} 949.53$, found 949.60

$\mathrm{H}-\mathbf{L Y R A N V}-\mathrm{S}-\mathrm{CH}_{2} \mathrm{CH}_{2} \mathrm{CO}-\mathbf{L}-\mathrm{NH}_{2}(\mathbf{6 c})(7.2 \mathrm{mg}, 14 \mu \mathrm{mol}, 31 \%$ isolated yield): Analytical HPLC conditions: linear gradient of solvent B in solvent A, $5 \%$ to $35 \%$ over $30 \mathrm{~min}$, retention time $=23.3$ min. Preparative HPLC conditions: linear gradient of solvent B in solvent A, $15 \%$ to $30 \%$ over $30 \mathrm{~min}$, retention time $=23.3 \mathrm{~min}$. LCMS (ESI-TOF) $\mathrm{m} / z$ calcd for $[\mathrm{M}+\mathrm{H}]^{+} 935.52$, found 935.60

H- LYRANS-S- $\mathrm{CH}_{2} \mathrm{CH}_{2} \mathrm{CO}-\boldsymbol{L}-\mathrm{NH}_{2}$ (6d) $(3.0 \mathrm{mg}, 2.3 \mu \mathrm{mol}, 9.0 \%$ isolated yield): Analytical HPLC conditions: linear gradient of solvent B in solvent A, $5 \%$ to $35 \%$ over 30 min, retention time $=18.3$ min. Preparative HPLC conditions: linear gradient of solvent B in solvent A, 15\% to $30 \%$ over $30 \mathrm{~min}$, retention time $=14.8 \mathrm{~min}$. LCMS (ESI-TOF) $\mathrm{m} / z$ calcd for $[\mathrm{M}+\mathrm{H}]^{+} 923.48$, found 923.50

$\mathrm{H}$ - LYRANK-S-CH${ }_{2} \mathrm{CH}_{2} \mathrm{CO}-\mathbf{L}-\mathrm{NH}_{2}$ (6e) $(5.8 \mathrm{mg}, 4.1 \mu \mathrm{mol}, 19 \%$ isolated yield): Analytical HPLC conditions: linear gradient of solvent B in solvent A, $5 \%$ to $35 \%$ over 30 min, retention time $=17.7$ min. Preparative HPLC conditions: linear gradient of solvent B in solvent A, 10\% to $20 \%$ over $30 \mathrm{~min}$, retention time $=16.0 \mathrm{~min}$. LCMS (ESI-TOF) $\mathrm{m} / z$ calcd for $[\mathrm{M}+\mathrm{H}]^{+} 964.54$, found 964.60

$\mathrm{H}$-GALYRGFA-S-CH $\mathrm{CH}_{2} \mathrm{CO}-\boldsymbol{G}-\mathrm{NH}_{2}(\mathbf{1 7})(16 \mathrm{mg}, 12 \mu \mathrm{mol}, 35 \%$ isolated yield): Analytical HPLC conditions: linear gradient of solvent B in solvent A, $5 \%$ to $45 \%$ over $30 \mathrm{~min}$, retention time $=18.4$ min. Preparative HPLC conditions: linear gradient of solvent B in solvent A, $15 \%$ to $25 \%$ over $30 \mathrm{~min}$, retention time $=16.7 \mathrm{~min}$. LCMS (ESI-TOF) $\mathrm{m} / z$ calcd for $[\mathrm{M}+\mathrm{H}]^{+} 998.49$, found 998.40

Peptides for cyclization

H-GALYRGFS-S- $\mathrm{CH}_{2} \mathrm{CH}_{2} \mathrm{CO}-\boldsymbol{G}-\mathrm{NH}_{2}$ (S1) $(26 \mathrm{mg}, 19 \mu \mathrm{mol}, 55 \%$ isolated yield): Analytical HPLC conditions: linear gradient of solvent B in solvent A, $5 \%$ to $45 \%$ over $30 \mathrm{~min}$, retention time $=17.0$ min. Preparative HPLC conditions: linear gradient of solvent B in solvent A, $15 \%$ to $25 \%$ over 30 min, retention time $=15.6 \mathrm{~min}$. LCMS (ESI-TOF) $\mathrm{m} / z$ calcd for $[\mathrm{M}+\mathrm{H}]^{+} 1014.49$, found 1014.50 
H-GALYRGFV-S-CH $\mathrm{CH}_{2} \mathrm{CO}-\boldsymbol{G}-\mathrm{NH}_{2}$ (S2) (24 mg, $18 \mu \mathrm{mol}, 51 \%$ isolated yield): Analytical HPLC conditions: linear gradient of solvent B in solvent A, $5 \%$ to $45 \%$ over 30 min, retention time $=21.3$ min. Preparative HPLC conditions: linear gradient of solvent B in solvent A, 15\% to $15 \%$ over $30 \mathrm{~min}$, retention time $=20.2 \mathrm{~min}$. LCMS $(\mathrm{ESI}-\mathrm{TOF}) \mathrm{m} / \mathrm{z}$ calcd for $[\mathrm{M}+\mathrm{H}]^{+} 1026.52$, found 1026.50

$\mathrm{H}$-FALYRGFA-S-CH $\mathrm{CH}_{2} \mathrm{CO}-\boldsymbol{G}-\mathrm{NH}_{2}$ (S3) (20 mg, $14 \mu \mathrm{mol}, 41 \%$ isolated yield): Analytical HPLC conditions: linear gradient of solvent B in solvent A, $5 \%$ to $45 \%$ over 30 min, retention time $=21.4$ min. Preparative HPLC conditions: linear gradient of solvent B in solvent A, 22\% to $32 \%$ over $30 \mathrm{~min}$, retention time $=\min$. LCMS $\left(\right.$ ESI-TOF) $\mathrm{m} / z$ calcd for $[\mathrm{M}+\mathrm{H}]^{+} 1088.54$, found 1088.55

$\mathrm{H}$-DALYRGFA-S-CH $\mathrm{CH}_{2} \mathrm{CO}-\boldsymbol{G}-\mathrm{NH}_{2}$ (S4) (25 mg, $18 \mu \mathrm{mol}, 52 \%$ isolated yield): Analytical HPLC conditions: linear gradient of solvent $\mathrm{B}$ in solvent A, $5 \%$ to $45 \%$ over $30 \mathrm{~min}$, retention time $=18.7 \mathrm{~min}$. Preparative HPLC conditions: linear gradient of solvent B in solvent A, $15 \%$ to $25 \%$ over $30 \mathrm{~min}$, retention time $=16.7 \mathrm{~min} . \mathrm{LCMS}(\mathrm{ESI}-\mathrm{TOF}) \mathrm{m} / z$ calcd for $[\mathrm{M}+\mathrm{H}]^{+} 1056.50$, found 1056.50

$\mathrm{H}$-NALYRGFA-S- $\mathrm{CH}_{2} \mathrm{CH}_{2} \mathrm{CO}-\boldsymbol{G}-\mathrm{NH}_{2}$ (S5) $(24 \mathrm{mg}, 24 \mu \mathrm{mol}, 68 \%$ isolated yield): Analytical HPLC conditions: linear gradient of solvent B in solvent A, $5 \%$ to $45 \%$ over 30 min, retention time $=18.4$ min. Preparative HPLC conditions: linear gradient of solvent B in solvent A, $15 \%$ to $25 \%$ over $30 \mathrm{~min}$, retention time $=16.7 \mathrm{~min} . \mathrm{LCMS}(\mathrm{ESI}-\mathrm{TOF}) \mathrm{m} / z$ calcd for $[\mathrm{M}+\mathrm{H}]^{+} 1055.51$, found 1055.50

$\mathrm{H}$-GALYRDFA-S- $\mathrm{CH}_{2} \mathrm{CH}_{2} \mathrm{CO}-\boldsymbol{G}-\mathrm{NH}_{2}$ (S6) $(23 \mathrm{mg}, 17 \mu \mathrm{mol}, 48 \%$ isolated yield): Analytical HPLC conditions: linear gradient of solvent B in solvent A, $5 \%$ to $45 \%$ over 30 min, retention time $=18.9$ min. Preparative HPLC conditions: linear gradient of solvent B in solvent A, $15 \%$ to $25 \%$ over $30 \mathrm{~min}$, retention time $=17.6 \mathrm{~min}$. LCMS (ESI-TOF) $\mathrm{m} / z$ calcd for $[\mathrm{M}+\mathrm{H}]^{+} 1056.50$, found 1056.50

Ac-SAFYG-S-CH${ }_{2} \mathrm{CH}_{2} \mathrm{CO}-\boldsymbol{L}-\mathrm{NH}_{2}(\mathbf{1 9})(6.1 \mathrm{mg}, 6.0 \mu \mathrm{mol}, 34 \%$ isolated yield): Analytical HPLC conditions: linear gradient of solvent B in solvent A, $10 \%$ to $40 \%$ over 30 min, retention time $=23.1$ min. Preparative HPLC conditions: linear gradient of solvent B in solvent A, 15\% to $30 \%$ over $30 \mathrm{~min}$, retention time $=23.4 \mathrm{~min}$. LCMS (ESI-TOF) $\mathrm{m} / z$ calcd for $[\mathrm{M}+\mathrm{H}]^{+} 786.35$, found 786.35

Peptides for evaluation of epimerization

$\mathrm{H}-\boldsymbol{L Y R} \boldsymbol{A N a}-\mathrm{S}-\mathrm{CH}_{2} \mathrm{CH}_{2} \mathrm{CO}-\boldsymbol{L}-\mathrm{NH}_{2}$ (S13) $(5.1 \mathrm{mg}, 4.0 \mu \mathrm{mol}, 16 \%$ isolated yield): Analytical HPLC conditions: linear gradient of solvent B in solvent A, $5 \%$ to $35 \%$ over $30 \mathrm{~min}$, retention time $=17.2$ min. Preparative HPLC conditions: linear gradient of solvent B in solvent A, $15 \%$ to $35 \%$ over 30 min, retention time $=13.4 \mathrm{~min}$. LCMS $(\mathrm{ESI}-\mathrm{TOF}) \mathrm{m} / z$ calcd for $[\mathrm{M}+\mathrm{H}]^{+} 907.48$, found 907.55.

H- LYRANs-S-CH $\mathrm{CH}_{2} \mathrm{CO}-\mathbf{L}-\mathrm{NH}_{2}$ (S14) $(3.0 \mathrm{mg}, 2.4 \mu \mathrm{mol}, 9.5 \%$ isolated yield): Analytical HPLC conditions: linear gradient of solvent B in solvent A, $5 \%$ to $35 \%$ over 30 min, retention time $=15.9$ min. Preparative HPLC conditions: linear gradient of solvent B in solvent A, $15 \%$ to $35 \%$ over $30 \mathrm{~min}$, retention time $=11.8 \mathrm{~min}$. LCMS $\left(\right.$ ESI-TOF) $\mathrm{m} / z$ calcd for $[\mathrm{M}+\mathrm{H}]^{+} 923.48$, found 923.50 . 
H-GALYRGFa-S- $\mathrm{CH}_{2} \mathrm{CH}_{2} \mathrm{CO}-\boldsymbol{G}-\mathrm{NH}_{2}$ (S15) (5.4 mg, $4.0 \mu \mathrm{mol}, 12 \%$ isolated yield): Analytical HPLC conditions: linear gradient of solvent B in solvent A, $5 \%$ to $45 \%$ over 30 min, retention time $=19.2$ min. Preparative HPLC conditions: linear gradient of solvent B in solvent A, $15 \%$ to $25 \%$ over $30 \mathrm{~min}$, retention time $=16.7 \mathrm{~min}$. LCMS $(\mathrm{ESI}-\mathrm{TOF}) \mathrm{m} / z$ calcd for $[\mathrm{M}+\mathrm{H}]^{+} 998.49$, found 998.50 .

$\mathrm{H}$-GALYRGFs-S-CH $\mathrm{CH}_{2} \mathrm{CO}-\boldsymbol{G}-\mathrm{NH}_{2}$ (S16) (22 mg, $16 \mu \mathrm{mol}, 46 \%$ isolated yield): Analytical HPLC conditions: linear gradient of solvent B in solvent A, $5 \%$ to $45 \%$ over 30 min, retention time $=17.8$ min. Preparative HPLC conditions: linear gradient of solvent B in solvent A, $15 \%$ to $25 \%$ over 30 min, retention time $=17.6 \mathrm{~min} . \mathrm{LCMS}(\mathrm{ESI}-\mathrm{TOF}) \mathrm{m} / z$ calcd for $[\mathrm{M}+\mathrm{H}]^{+} 1014.49$, found 1014.50. 


\section{Synthesis of peptide 7, S21.}

\section{Synthesis of N-terminal cysteinyl peptides for intermolecular NCL reactions (7 and S21).}

The protected peptide resin was constructed on NovaSyn ${ }^{\circledR}$ TGR resin $(0.22 \mathrm{mmol}$ amine/g) using manual Fmoc SPPS procedure as described in general information. The final deprotection was carried out by TFA/ $\mathrm{Et}_{3} \mathrm{SiH} / \mathrm{H}_{2} \mathrm{O}(95 / 2.5 / 2.5(\mathrm{v} / \mathrm{v}))(50 \mu \mathrm{L} / 1 \mathrm{mg}$ resin) for $2 \mathrm{~h}$. After filtration of the resin, cooled $\mathrm{Et}_{2} \mathrm{O}$ was added to the filtrate to give precipitate. The resulting precipitate was collected by centrifugation and thoroughly washed with $\mathrm{Et}_{2} \mathrm{O}$ to afford crude product, which was purified by preparative HPLC to yield the title peptides.

H-CSPGYS-NH2 (7) (19 mg, 37\%). Analytical HPLC conditions: linear gradient of solvent B in solvent A, $5 \%$ to $35 \%$ over 30 min, retention time $=9.8$ min. Preparative HPLC conditions: linear gradient of solvent B in solvent A, 15\% to $30 \%$ over $30 \mathrm{~min}$, retention time $=14.8 \mathrm{~min}$. LCMS (ESITOF) $\mathrm{m} / z$ calcd for $[\mathrm{M}+\mathrm{H}]^{+} 612.42$, found 612.45 .

H-CYRANKYK-NH $H_{2}$ (S21) (34 mg, 33\%). Analytical HPLC conditions: linear gradient of solvent B in solvent A, $5 \%$ to $35 \%$ over $30 \mathrm{~min}$, retention time $=10.0 \mathrm{~min}$. Preparative HPLC conditions: linear gradient of solvent $\mathrm{B}$ in solvent A, $7 \%$ to $17 \%$ over $30 \mathrm{~min}$, retention time $=18.2 \mathrm{~min}$. LCMS (ESITOF) $\mathrm{m} / \mathrm{z}$ calcd for $[\mathrm{M}+2 \mathrm{H}]^{2+} 522.77$, found 522.80 .

\section{Synthesis of thioester peptides (S7-S12) ${ }^{\text {SI). }}$}

\section{Synthesis of thioester peptides used for cyclization reactions (S7-S12).}

Title thioester peptides (S7-S12) were constructed on hydrazine 2-Cl Trt resin by Fmoc SPPS. 2-Cl Trt resin $(2.0 \mathrm{~g})$ was swelled in DMF $(10 \mathrm{~mL})$ for $15 \mathrm{~min}$. The mixture solution was placed in ice bath $\left(0{ }^{\circ} \mathrm{C}\right)$. Then a solution of hydrazine in DMF (triethylamine: hydrazine monohydrate: $\mathrm{DMF}=1.3 \mathrm{~mL}$ : $0.31 \mathrm{~mL}: 4.0 \mathrm{~mL})$ was added dropwise. After $1.5 \mathrm{~h}$, methanol $(0.2 \mathrm{~mL})$ was added. After $10 \mathrm{~min}$ reaction, the resulting resin was successively washed with DMF, $\mathrm{H}_{2} \mathrm{O}$ and $\mathrm{MeOH}$. The $\mathrm{H}_{2} \mathrm{NHN}-$ functionalized resin was dried under vacuum and can be used directly for SPPS. The peptide chain was elongated on this resin using a Fmoc SPPS procedure as described in the general information. The completed resin was treated with TFA/TIS/ $\mathrm{H}_{2} \mathrm{O} / m$-cresol/thioanisole $(75 / 2.5 / 2.5 / 5 / 15(\mathrm{v} / \mathrm{v}))(50 \mu \mathrm{L} / 1$ mg resin) at a low temperature chamber $\left(4{ }^{\circ} \mathrm{C}\right)$. After $2 \mathrm{~h}, 10 \%$ (w/w) $\mathrm{NaNO}_{2}$ aq. $(20 \mu \mathrm{L} / \mathrm{mL})$ was added to the mixture at $-10{ }^{\circ} \mathrm{C}$. Stored at $-10{ }^{\circ} \mathrm{C}$ for $20 \mathrm{~min}$, cold $\mathrm{Et}_{2} \mathrm{O}$ was added to the reaction mixture to give a precipitate. The formed precipitate was collected by centrifugation and thoroughly washed with $\mathrm{Et}_{2} \mathrm{O}$ to afford crude peptide azide. To the crude product was added 3\% (v/v) 3mercaptopropionic acid (MPA) in buffer ( $6 \mathrm{M} \mathrm{Gn} \cdot \mathrm{HCl}, 50 \mathrm{mM}$ phosphate, $\mathrm{pH} 7.3)(60 \mu \mathrm{L} / 1 \mathrm{mg}$ resin). After $30 \mathrm{~min}$ at room temperature, $0.1 \%$ TFA aq. as much as the volume of the buffer was added to quench the thiolysis. The crude material in the thiolysis buffer was purified by preparative HPLC to yield the title peptides $\mathbf{S 7 - 1 2}$. 
$\mathrm{H}$-GLYRA-S- $\mathrm{CH}_{2} \mathrm{CH}_{2} \mathrm{CO}_{2} \mathrm{H}$ (S7) (1.9 mg, $2.2 \mu \mathrm{mol}, 14 \%$ isolated yield): Analytical HPLC conditions: linear gradient of solvent $\mathrm{B}$ in solvent $\mathrm{A}, 5 \%$ to $45 \%$ over $30 \mathrm{~min}$, retention time $=16.0 \mathrm{~min}$. Preparative HPLC conditions: linear gradient of solvent B in solvent A, $15 \%$ to $30 \%$ over $30 \mathrm{~min}$, retention time $=23.7 \mathrm{~min}$. LCMS $(\mathrm{ESI}-\mathrm{TOF}) \mathrm{m} / \mathrm{z}$ calcd for $[\mathrm{M}+\mathrm{H}]^{+} 667.33$, found 667.35 .

$\mathrm{H}$-GGLYRA-S- $\mathrm{CH}_{2} \mathrm{CH}_{2} \mathrm{CO}_{2} \mathrm{H}$ (S8) $(1.3 \mathrm{mg}, 1.3 \mu \mathrm{mol}, 7 \%$ isolated yield): Analytical HPLC conditions: linear gradient of solvent B in solvent A, $5 \%$ to $45 \%$ over 30 min, retention time $=16.2$ min. Preparative HPLC conditions: linear gradient of solvent B in solvent A, $15 \%$ to $30 \%$ over $30 \mathrm{~min}$, retention time $=23.8 \mathrm{~min}$. LCMS $\left(\right.$ ESI-TOF) $\mathrm{m} / z$ calcd for $[\mathrm{M}+\mathrm{H}]^{+} 724.35$, found 724.35 .

$\mathrm{H}$-GNGLYRA-S- $\mathrm{CH}_{2} \mathrm{CH}_{2} \mathrm{CO}_{2} \mathrm{H}$ (S9) $(2.4 \mathrm{mg}, 2.2 \mu \mathrm{mol}, 12 \%$ isolated yield): Analytical HPLC conditions: linear gradient of solvent B in solvent A, $5 \%$ to $45 \%$ over 30 min, retention time $=16.1$ min. Preparative HPLC conditions: linear gradient of solvent B in solvent A, $15 \%$ to $30 \%$ over 30 min, retention time $=23.5 \mathrm{~min}$. LCMS $(\mathrm{ESI}-\mathrm{TOF}) \mathrm{m} / \mathrm{z}$ calcd for $[\mathrm{M}+\mathrm{H}]^{+} 838.39$, found 838.40 .

$\mathrm{H}$-GANGLYRA-S- $\mathrm{CH}_{2} \mathrm{CH}_{2} \mathrm{CO}_{2} \mathrm{H}$ (S10) $(2.0 \mathrm{mg}, 1.8 \mu \mathrm{mol}, 10 \%$ isolated yield): Analytical HPLC conditions: linear gradient of solvent B in solvent A, $5 \%$ to $45 \%$ over 30 min, retention time $=16.4$ min. Preparative HPLC conditions: linear gradient of solvent B in solvent A, $15 \%$ to $30 \%$ over 30 min, retention time $=24.2 \mathrm{~min}$. LCMS (ESI-TOF) $\mathrm{m} / z$ calcd for $[\mathrm{M}+\mathrm{H}]^{+} 909.43$, found 909.45 .

$\mathrm{H}$-GRANGLYRA-S- $\mathrm{CH}_{2} \mathrm{CH}_{2} \mathrm{CO}_{2} \mathrm{H}$ (S11) (2.2 mg, $1.8 \mu \mathrm{mol}, 9.0 \%$ isolated yield): Analytical HPLC conditions: linear gradient of solvent B in solvent A, $5 \%$ to $45 \%$ over 30 min, retention time $=15.9$ min. Preparative HPLC conditions: linear gradient of solvent B in solvent A, 15\% to $30 \%$ over 30 min, retention time $=22.7 \mathrm{~min} . \mathrm{LCMS}\left(\right.$ ESI-TOF) $\mathrm{m} / z$ calcd for $[\mathrm{M}+\mathrm{H}]^{+} 1065.53$, found 1065.50

$\mathrm{H}$-GLRANGLYRA-S- $\mathrm{CH}_{2} \mathrm{CH}_{2} \mathrm{CO}_{2} \mathrm{H}$ (S12) $(2.8 \mathrm{mg}, 1.8 \mu \mathrm{mol}, 11 \%$ isolated yield): Analytical HPLC conditions: linear gradient of solvent B in solvent A, $5 \%$ to $45 \%$ over $30 \mathrm{~min}$, retention time $=17.7$ min. Preparative HPLC conditions: linear gradient of solvent B in solvent A, $15 \%$ to $30 \%$ over 30 $\mathrm{min}$, retention time $=28.6 \mathrm{~min}$. LCMS $(\mathrm{ESI}-\mathrm{TOF}) \mathrm{m} / z$ calcd for $[\mathrm{M}+\mathrm{H}]^{+} 1178.61$, found 1178.60 . 
(A)

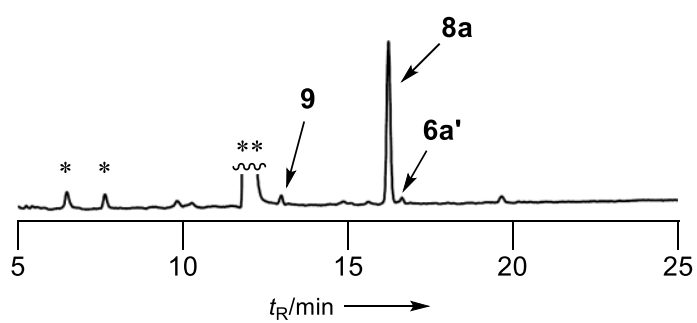

(C)

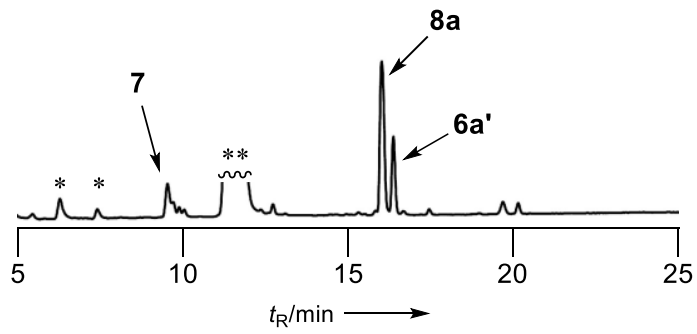

(E)

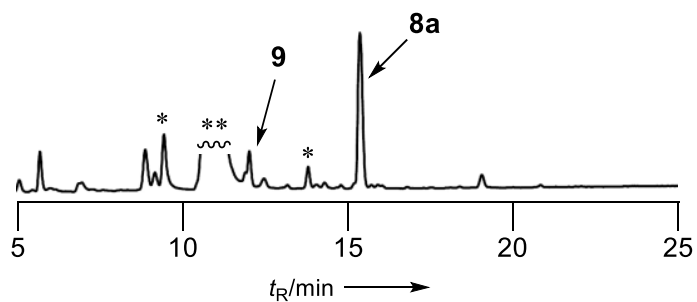

(B)

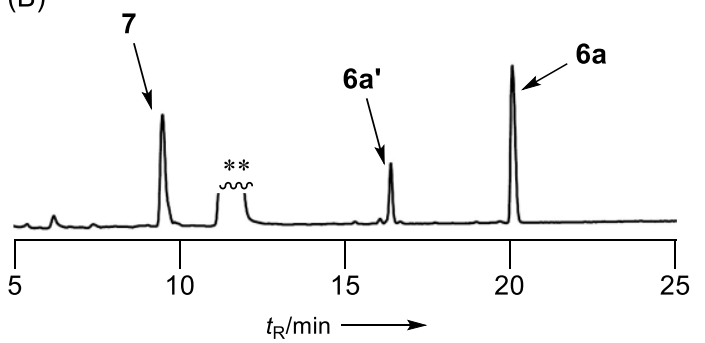

(D)

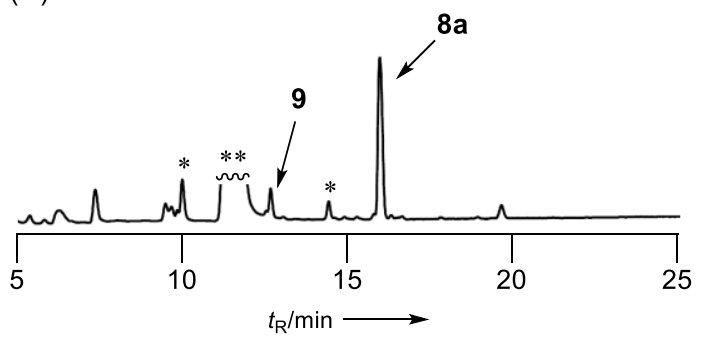

\begin{tabular}{ccc}
\hline entry & $\mathbf{p H}$ & conversion $^{\mathrm{a}}\left(\mathbf{6 a}: \mathbf{8 a}: \mathbf{6} \mathbf{a}^{\mathbf{9}} \mathbf{9}\right)(\%)$ \\
\hline 1 & 6.9 & $0: 94: 2: 4$ \\
2 & 4.0 & $78: 1: 21: 0$ \\
3 & 6.0 & $0: 70: 27: 3$ \\
4 & 8.0 & $0: 89: 0: 11$ \\
5 & 10.0 & $0: 86: 0: 14$ \\
\hline
\end{tabular}

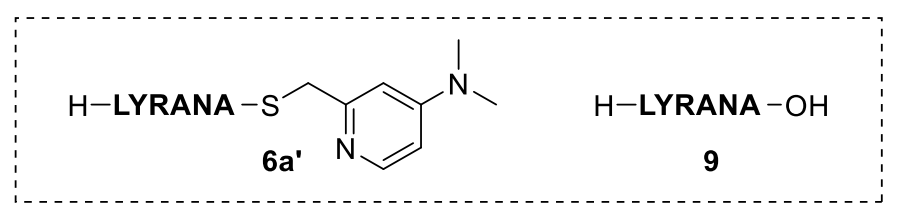

Figure S1. Analytical HPLC charts of NCL buffer at various pH. (A) Entry 1 (pH 6.9); (B) Entry 2 (pH 4.0); (C) Entry 3 (pH 6.0); (D) Entry 4 (pH 8.0); (E) Entry 5 (pH 10.0); ${ }^{a}$ conversion: 100*integ. (6a, 8a, 6a' or 9) / integ. (thioester derived peptides). Analytical HPLC conditions: linear gradient of solvent $\mathrm{B}$ in solvent $\mathrm{A}, 5 \%$ to $35 \%$ over $30 \mathrm{~min}$. *Non-peptide impurity; **SMDMAP. $H$ LYRANACSPGYS-NH $\mathrm{H}_{2}$ (8a): Analytical HPLC condition, linear gradient of solvent B in solvent A, 5 to $35 \%$ over $30 \mathrm{~min}$, retention time $=16.1 \mathrm{~min}, \mathrm{MS}(\mathrm{ESI}-\mathrm{TOF}) \mathrm{m} / \mathrm{z}$ calcd for $[\mathrm{M}+2 \mathrm{H}]^{2+} 650.81$, found 650.90 .

H-LYRANA-SMDMAP (6a'): Analytical HPLC condition, linear gradient of solvent B in solvent A, 5 to $35 \%$ over $30 \mathrm{~min}$, retention time $=16.4 \mathrm{~min}$, MS $(\mathrm{ESI}-\mathrm{TOF}) \mathrm{m} / \mathrm{z}$ calcd for $[\mathrm{M}+\mathrm{H}]^{+} 857.45$, found 857.45 .

H-LYRANA-OH (9): Analytical HPLC condition, linear gradient of solvent B in solvent A, 5 to $35 \%$ over $30 \mathrm{~min}$, retention time $=12.7 \mathrm{~min}$, MS $(\mathrm{ESI}-\mathrm{TOF}) \mathrm{m} / \mathrm{z}$ calcd for $[\mathrm{M}+\mathrm{H}]^{+} 707.39$, found 707.4. 
Examination of side reaction at $\varepsilon$-amino group in SMDMAP-mediated NCL reaction

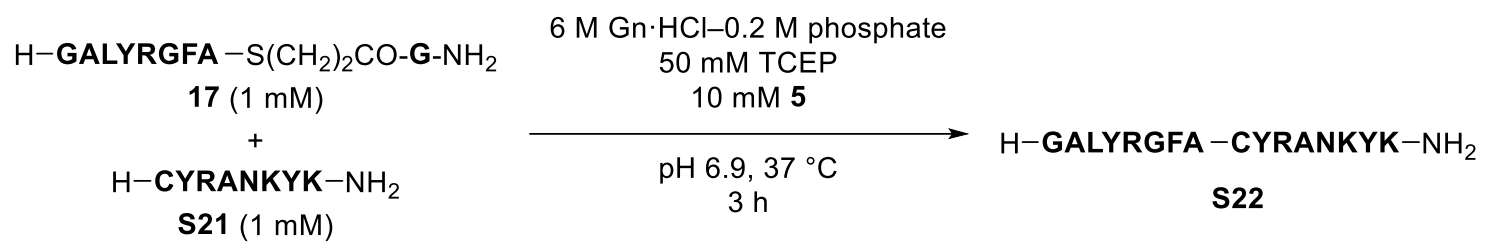

(A)

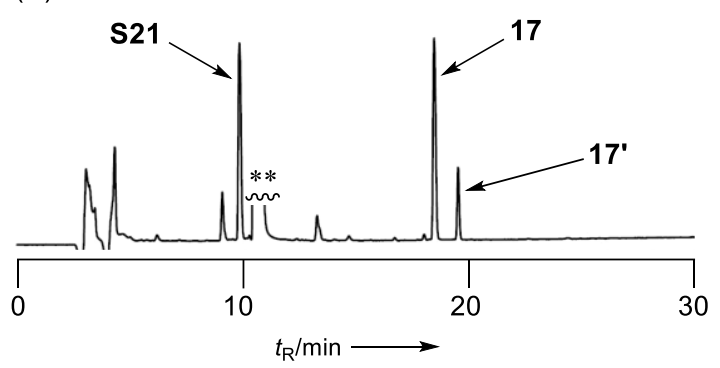

(B)

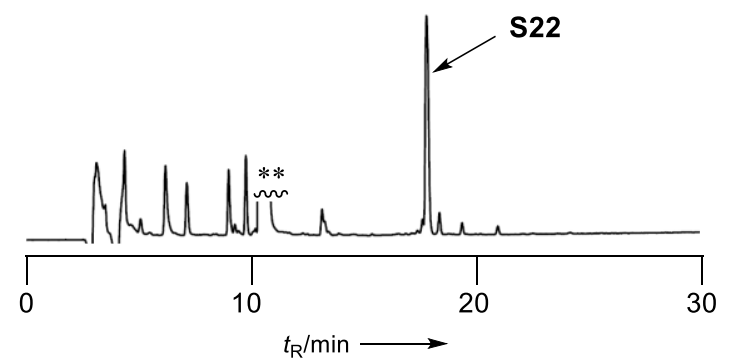

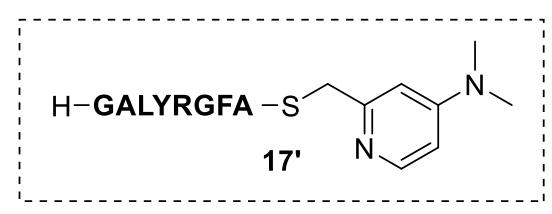

Figure S2. Analytical HPLC charts of NCL buffer at various pH. (A) NCL: $t<5 \mathrm{~min}$; (B) NCL: $t=3$ h. Analytical HPLC conditions: linear gradient of solvent B in solvent A, 5\% to $45 \%$ over $30 \mathrm{~min}$. *Non-peptide impurity; **SMDMAP.

H-GALYRGFA-SMDMAP (17'): Analytical HPLC condition, linear gradient of solvent B in solvent A, 5 to $35 \%$ over $30 \mathrm{~min}$, retention time $=19.5 \mathrm{~min}$, MS (ESI-TOF) $\mathrm{m} / \mathrm{z}$ calcd for $[\mathrm{M}+2 \mathrm{H}]^{2+} 502.77$, found 502.75 .

H-GALYRGFACYRANKYK- $\mathrm{NH}_{2}$ (S22): Analytical HPLC condition, linear gradient of solvent B in solvent A, 5 to $35 \%$ over $30 \mathrm{~min}$, retention time $=18.3 \mathrm{~min}, \mathrm{MS}(\mathrm{ESI}-\mathrm{TOF}) \mathrm{m} / \mathrm{z}$ calcd for $[\mathrm{M}+2 \mathrm{H}]^{2+}$ 940.50, found 940.55 . 
Substrate versatility in SMDMAP-mediated NCL reaction

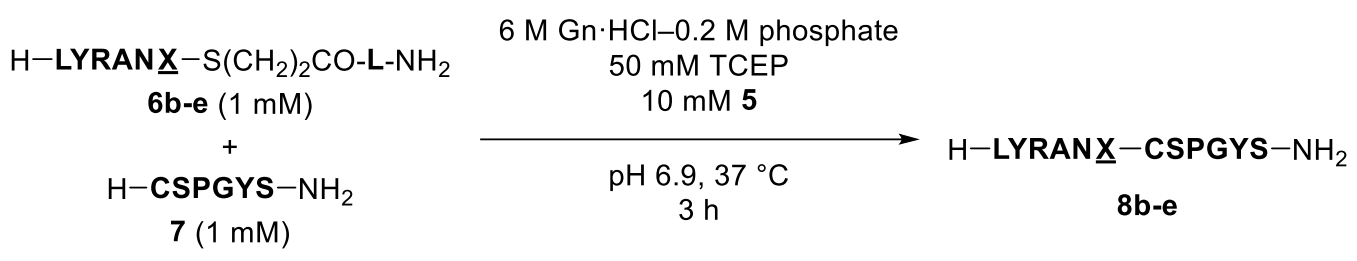

(A)

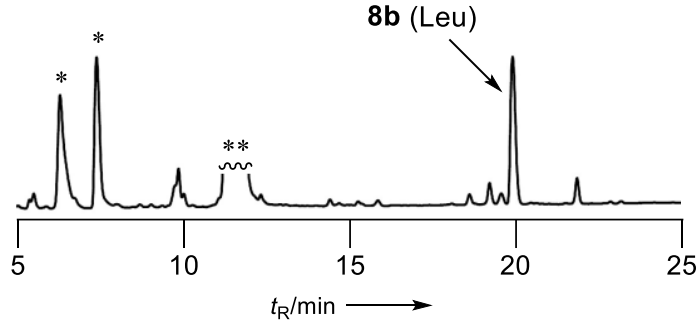

(C)

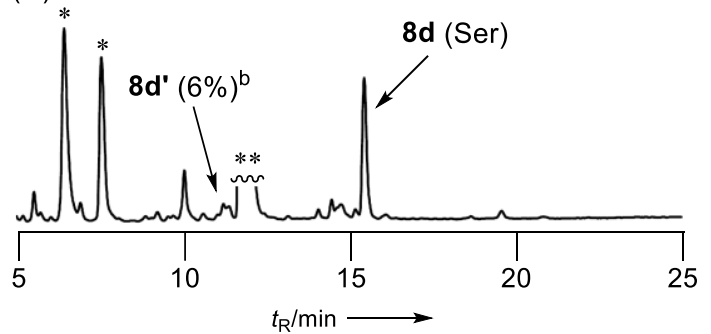

$(B)^{a}$

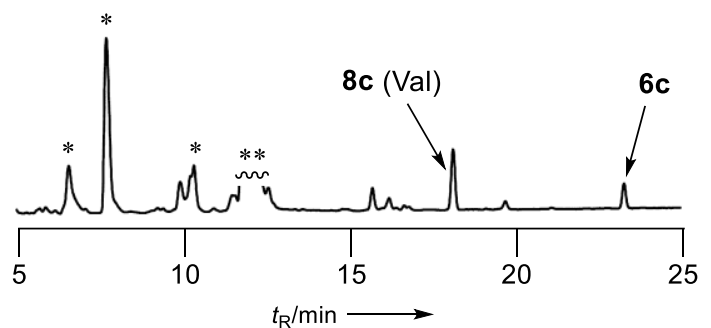

(D)

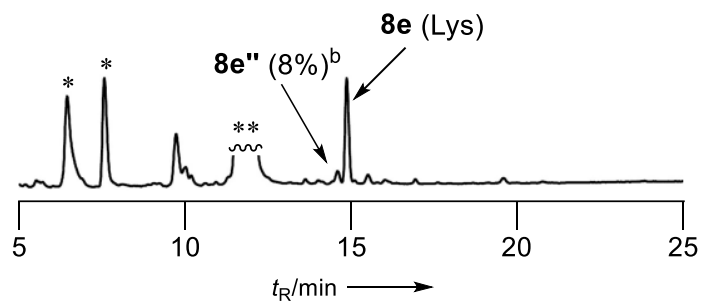

Figure S3. Analytical HPLC charts of NCL using several thioesters. (A) $\mathbf{6 b}(\mathrm{X}=\mathrm{Leu})$; (B) $\mathbf{6 c}(\mathrm{X}=$ Val); (C) 6d $(\mathrm{X}=\mathrm{Ser})$; (D) 6e (X = Lys). ${ }^{\mathrm{a}}$ The reaction was performed at $50^{\circ} \mathrm{C}$.; ${ }^{\mathrm{b}}$ Ratio $(\mathbf{8 d}$ ' or 8e") was calculated by the following equation. Ratio $\left(\mathbf{8 d}\right.$ ' or $\left.8 \mathbf{e}^{\prime \prime}\right)=100 *$ integ. (8d' or $\mathbf{8 e}$ ") / integ. (Thioester-derived peptides). Analytical HPLC conditions: linear gradient of solvent B in solvent A, $5 \%$ to $35 \%$ over $30 \mathrm{~min}$. Non-peptide impurity; ** SMDMAP. 
H-LYRANLCSPGYS-NH $\mathrm{NH}_{2}(\mathbf{8 b})$ : Analytical HPLC condition, linear gradient of solvent B in solvent A, 5 to $35 \%$ over $30 \mathrm{~min}$, retention time $=19.9 \mathrm{~min}$, MS (ESI-TOF) $\mathrm{m} / z$ calcd for $[\mathrm{M}+2 \mathrm{H}]^{2+} 671.84$, found 671.95 .

H-LYRANVCSPGYS- $\mathrm{NH}_{2}$ (8c): Analytical HPLC condition, linear gradient of solvent B in solvent A, 5 to $35 \%$ over $30 \mathrm{~min}$, retention time $=18.1 \mathrm{~min}$, MS (ESI-TOF) $\mathrm{m} / z$ calcd for $[\mathrm{M}+2 \mathrm{H}]^{2+} 664.83$, found 664.85 .

H-LYRANSCSPGYS- $\mathrm{NH}_{2}$ (8d): Analytical HPLC condition, linear gradient of solvent B in solvent A, 5 to $35 \%$ over $30 \mathrm{~min}$, retention time $=15.4 \mathrm{~min}$, MS (ESI-TOF) $\mathrm{m} / z$ calcd for $[\mathrm{M}+2 \mathrm{H}]^{2+} 658.81$, found 658.90 .

H-LYRANKCSPGYS- $\mathrm{NH}_{2}$ (8e): Analytical HPLC condition, linear gradient of solvent B in solvent A, 5 to $35 \%$ over $30 \mathrm{~min}$, retention time $=14.8 \mathrm{~min}$, MS (ESI-TOF) $\mathrm{m} / \mathrm{z}$ calcd for $[\mathrm{M}+2 \mathrm{H}]^{2+} 679.34$, found 679.40 .

H-LYRANS-OH (8d'): Analytical HPLC condition, linear gradient of solvent B in solvent A, 5 to 35\% over $30 \mathrm{~min}$, retention time $=11.2 \mathrm{~min}$, MS $\left(\right.$ ESI-TOF) $\mathrm{m} / \mathrm{z}$ calcd for $[\mathrm{M}+\mathrm{H}]^{+} 723.38$, found 723.40 .

H-LYRANcyclo(K) (8e"): Analytical HPLC condition, linear gradient of solvent B in solvent A, 5 to $35 \%$ over $30 \mathrm{~min}$, retention time $=14.6 \mathrm{~min}$, MS (ESI-TOF) $\mathrm{m} / \mathrm{z}$ calcd for $[\mathrm{M}+\mathrm{H}]^{+} 746.43$, found 746.45 . 
Verification of epimerization of C-terminal chiral amino acids during NCL

\section{Evaluation of epimerization occurring in intermolecular NCL reaction of 6a (or 6d) with 7}

NCL reaction of $6 \mathbf{6}$ (or $\mathbf{6 d}$ ) with 7 ( $1 \mathrm{mM}$ each) was performed in $6 \mathrm{M} \mathrm{Gn} \cdot \mathrm{HCl}-0.2 \mathrm{M}$ Na phosphate buffer $(\mathrm{pH} 6.9,50 \mu \mathrm{L})$ containing $50 \mathrm{mM}$ TCEP and $10 \mathrm{mM}$ of $5 \cdot 2 \mathrm{HCl}$ at $37{ }^{\circ} \mathrm{C}$ for $3 \mathrm{~h}$ and the reactions were analyzed by HPLC analysis. For obtaining reference peptides $\mathbf{S 1 7}$ or $\mathbf{S 1 8}$ for evaluation of epimerization, NCL using $\mathbf{S 1 3}$ or $\mathbf{S 1 4}$ as the C-terminal D-thioester peptides in the presence of 50 mM TCEP and 20 mM MPAA were conducted.

(A)

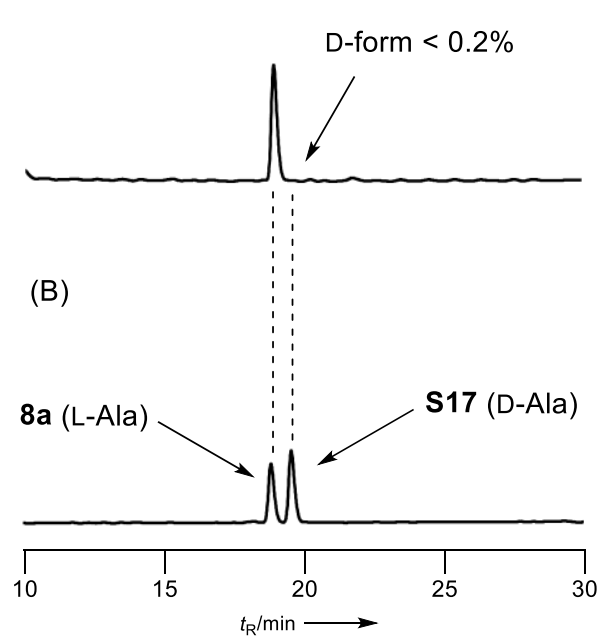

(C)

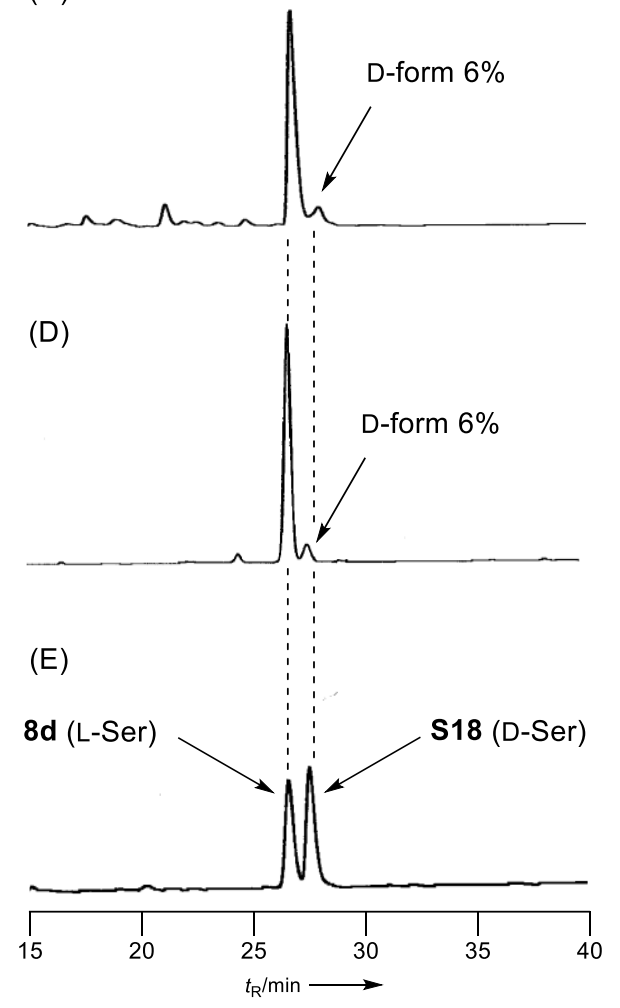

Figure S4. Verification of epimerization of C-terminal chiral amino acids during SMDMAP-mediated NCL. (A) Crude reaction material (Substrate 6a), $t=3 \mathrm{~h}$; (B) Co-injection 8a with S17; (C) Crude reaction material (substrate 6d), $t=3 \mathrm{~h}$; (D) Crude reaction material (added MPAA instead of SMDMAP); (E) Co-injection 8d with S18; Analytical HPLC conditions: Cosmosil 5C 18 AR-II column $(4.6 \times 250 \mathrm{~mm})$ with a linear gradient of solvent B in solvent A, (Chart (A), (B): 10:90-20:80 over 30 min, Chart (C), (D): 10:90-15:85 over $40 \mathrm{~min}$ ) at a flow rate $1.0 \mathrm{~mL} / \mathrm{min}$, detection at $220 \mathrm{~nm}$. 
H-LYRANaCSPGYS-NH $\mathrm{H}_{2}$ (S17): Analytical HPLC condition, linear gradient of solvent B in solvent A, 10 to $20 \%$ over $30 \mathrm{~min}$, retention time $=19.5 \mathrm{~min}, \mathrm{MS}(\mathrm{ESI}-\mathrm{TOF}) \mathrm{m} / \mathrm{z}$ calcd for $[\mathrm{M}+2 \mathrm{H}]^{2+} 650.81$, found 650.80 .

H-LYRANSCSPGYS- $\mathrm{NH}_{2}$ (S18): Analytical HPLC condition, linear gradient of solvent B in solvent A, 10 to $15 \%$ over $40 \mathrm{~min}$, retention time $=27.8 \mathrm{~min}, \mathrm{MS}\left(\right.$ ESI-TOF) $\mathrm{m} / \mathrm{z}$ calcd for $[\mathrm{M}+2 \mathrm{H}]^{2+} 659.24$, found 659.25 . 


\section{SMDMAP-mediated One-pot/NCL-desulfurization reaction}

NCL of thioester peptide $6 \mathbf{a}(0.05 \mu \mathrm{mol})$ and N-terminal cysteinyl peptide $7(0.05 \mu \mathrm{mol})$ in $6 \mathrm{M}$ $\mathrm{Gn} \cdot \mathrm{HCl}-0.2 \mathrm{M}$ Na phosphate buffer $(\mathrm{pH} 6.9,50 \mu \mathrm{L})$ containing $50 \mathrm{mM}$ TCEP and $10 \mathrm{mM}$ of $5 \cdot 2 \mathrm{HCl}$ at $37^{\circ} \mathrm{C}$ for $3 \mathrm{~h}$ reached completion to give the reaction mixture containing 1 st NCL product $8 \mathbf{a}$. Then, the desulfurization of $8 \mathbf{a}$ was initiated by the addition of $0.2 \mathrm{M} \mathrm{Na}$ phosphate buffer $(50 \mu \mathrm{L})$ containing $400 \mathrm{mM}$ TCEP, $160 \mathrm{mM}$ VA-044 and $160 \mathrm{mM}$ glutathione to the ligation mixture. After being stirred at $37^{\circ} \mathrm{C}$ for $3 \mathrm{~h}$, the reaction afforded the desulfurization product 10 . Quenching the desulfurization was perfomed by the addition of the same volume of $6 \mathrm{M} \mathrm{Gn} \cdot \mathrm{HCl}-100 \mathrm{mM} \mathrm{Na}$ ascorbate solution as the desulfurization solution.

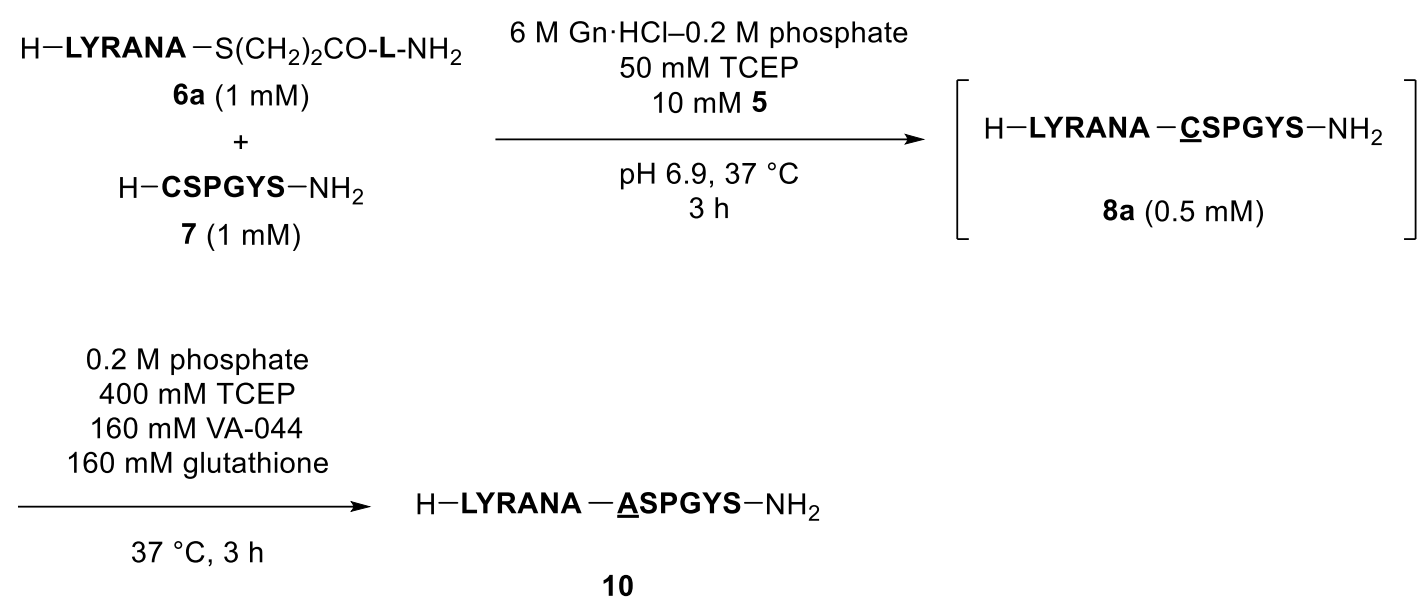

(A)

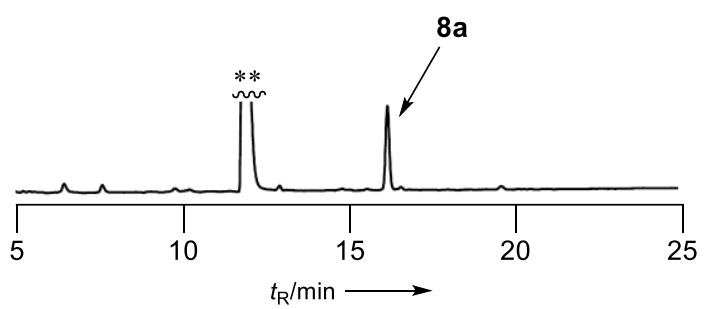

(B)

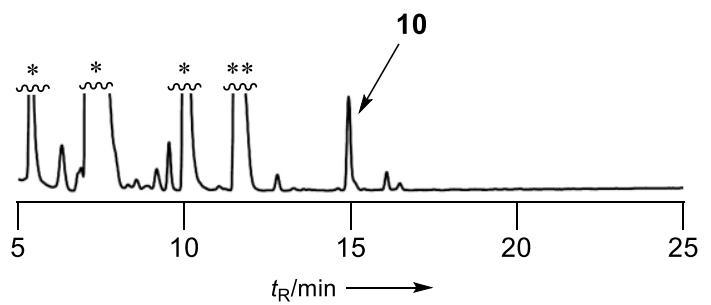

Figure S5. Analytical HPLC charts of crude reaction material. (A) NCL: $t=3 \mathrm{~h}$; (B) One-pot/NCLdesulfurization: $t=4 \mathrm{~h}$. Analytical HPLC conditions: linear gradient of solvent B in solvent A, $5 \%$ to $35 \%$ over 30 min. *Non-peptide impurity; ** SMDMAP.

H-LYRANAASPGYS- $\mathrm{NH}_{2}$ (10): Analytical HPLC condition, linear gradient of solvent B in solvent A, 5 to $35 \%$ over $30 \mathrm{~min}$, retention time $=15.0 \mathrm{~min}$, MS (ESI-TOF) $\mathrm{m} / z$ calcd for $[\mathrm{M}+2 \mathrm{H}]^{2+} 634.83$, found 634.90 . 
One-pot/N-to-C or C-to-N directed NCLs-desulfurization (Figure 3, 4 original chart)

Synthesis of thioester peptides for the use for One-pot/N-to-C or $\mathbf{C}-$ to $-\mathrm{N}$ directed NCLsdesulfurization.

\section{Synthesis of SEAlide peptide $12^{\text {S2). }}$}

On NovaSyn ${ }^{\circledR}$ TGR resin $(0.22 \mathrm{mmol}$ amine/g), Fmoc-Gly-OH (4.0 eq.) was coupled in the presence of DIPCI (4.0 eq.), $\mathrm{HOBt} \cdot \mathrm{H}_{2} \mathrm{O}$ (4.0 eq.) in DMF at room temperature for $2 \mathrm{~h}$. Then removal of Fmoc groups was carried out using 20\% (v/v) piperidine in DMF for $10 \mathrm{~min}$ at room temperature. Next, treatment of the resulting resin with Fmoc-AA-incorporating SEAlide unit (4.0 eq.), DIPCI (4.0 eq.), $\mathrm{HOBt} \cdot \mathrm{H}_{2} \mathrm{O}$ (4.0 eq.) in DMF at room temperature for $2 \mathrm{~h}$. The peptide chain was elongated on this resin using a Fmoc SPPS procedure as described in the general information. The completed resin was treated with $\mathrm{TFA} / \mathrm{Et}_{3} \mathrm{SiH} / \mathrm{H}_{2} \mathrm{O}(95 / 2.5 / 2.5(\mathrm{v} / \mathrm{v}), 50 \mu \mathrm{L} / 1 \mathrm{mg}$ resin) at room temperature for $2 \mathrm{~h}$. After filtration of the resin, cooled $\mathrm{Et}_{2} \mathrm{O}$ was added to the filtrate to give precipitate. The formed precipitate was collected by centrifugation and thoroughly washed with $\mathrm{Et}_{2} \mathrm{O}$ to afford crude peptides. The crude peptide was purified by preparative HPLC to give the purified SEAlide peptides.

H-CLYRANA-SEAlide-G-NH2 (12) $(29 \mathrm{mg}, 23 \mu \mathrm{mol}, 43 \%$ isolated yield): Analytical HPLC conditions: linear gradient of solvent B in solvent A, $5 \%$ to $35 \%$ over 30 min, retention time $=16.2$ min. Preparative HPLC conditions: linear gradient of solvent B in solvent A, $13 \%$ to $28 \%$ over 30 min, retention time $=24.2 \mathrm{~min}$. LCMS $(\mathrm{ESI}-\mathrm{TOF}) \mathrm{m} / \mathrm{z}$ calcd for $[\mathrm{M}+\mathrm{H}]^{+} 1045.47$, found 1045.50

\section{Synthesis of N-terminal Thz-SMDMAP thioester peptides (15).}

Title thioester peptide (15) was constructed on hydrazine 2-Cl Trt resin by Fmoc SPPS. The elongated peptide was cleaved from resin to gain peptide hydrazide. And then, this peptide was converted into peptide azide (procedure: see synthesis of thioester peptides (S7-12)). To the crude product was added $50 \mathrm{mM}$ of $\mathbf{5} \cdot 2 \mathrm{HCl}$ and $25 \mathrm{mM}$ TCEP in buffer $(6 \mathrm{M} \mathrm{Gn} \cdot \mathrm{HCl}, 0.2 \mathrm{M}$ Na phosphate, $\mathrm{pH} 6.5)(60 \mu \mathrm{L} / 1$ $\mathrm{mg}$ resin). After $30 \mathrm{~min}$ at room temperature, $0.1 \%$ TFA aq. as much as the volume of the buffer was added to quench the thiolysis. The crude material in the thiolysis buffer was purified by preparative HPLC to yield the title peptide $\mathbf{1 5 .}$

H-ThzLYRANA-SMDMAP(15) (9.2 mg, $6.4 \mu \mathrm{mol}, 46 \%$ isolated yield): Analytical HPLC conditions: linear gradient of solvent $\mathrm{B}$ in solvent $\mathrm{A}, 5 \%$ to $35 \%$ over $30 \mathrm{~min}$, retention time $=15.7 \mathrm{~min}$. Preparative HPLC conditions: linear gradient of solvent B in solvent A, 9\% to $19 \%$ over $30 \mathrm{~min}$, retention time $=24.9 \mathrm{~min}$. LCMS (ESI-TOF) $\mathrm{m} / z$ calcd for $[\mathrm{M}+\mathrm{H}]^{+} 972.46$, found 972.50 . 
One-pot/three-fragment NCL-desulfurization ( $N$-to-C protocol) using SEAlide peptides (Figure 3 and Figure S6).

Thioester peptide 6a $(0.05 \mu \mathrm{mol})$ and N-terminal cysteinyl SEAlide peptide $12(0.50 \mu \mathrm{mol})$ were dissolved in $6 \mathrm{M} \mathrm{Gn} \cdot \mathrm{HCl}-0.1 \mathrm{M}$ HEPPS buffer $(\mathrm{pH} 6.9,50 \mu \mathrm{L})$ containing $50 \mathrm{mM}$ TCEP and $10 \mathrm{mM}$ $5 \cdot 2 \mathrm{HCl}$, the mixture was stirred at $37^{\circ} \mathrm{C}$. After $4 \mathrm{~h}$ reaction (Figures 3 (A) and S6(A)), a solution of $\mathrm{N}$-terminal cysteinyl peptide $7(0.05 \mu \mathrm{mol})$ in $1 \mathrm{M} \mathrm{Na}$ phosphate buffer $(\mathrm{pH} 6.9,50 \mu \mathrm{L})$ containing 50 $\mathrm{mM}$ TCEP and $10 \mathrm{mM}$ of $5 \cdot 2 \mathrm{HCl}$ was added to the $1 \mathrm{st}$ NCL mixture with additional stirring at $50{ }^{\circ} \mathrm{C}$ for $7 \mathrm{~h}$ (Figures 3(B) and S6(B)). Then, the desulfurization buffer containing $600 \mathrm{mM}$ TCEP, $240 \mathrm{mM}$ VA-044 and $240 \mathrm{mM}$ glutathione in $0.2 \mathrm{M}$ Na phosphate buffer $(50 \mu \mathrm{L})$ was added to the reaction mixture. After $6 \mathrm{~h}$ reaction (Figures $3(\mathrm{C})$ and $\mathrm{S} 6(\mathrm{C})$ ), the same volume of the quenching buffer containing $100 \mathrm{mM} \mathrm{Na}$ ascorbate in $6 \mathrm{M} \mathrm{Gn} \cdot \mathrm{HCl}$ as the desulfurization mixture was added. The mixture was directly brought to semi-preparative HPLC purification to give 11 in $44 \%$ isolated yield.

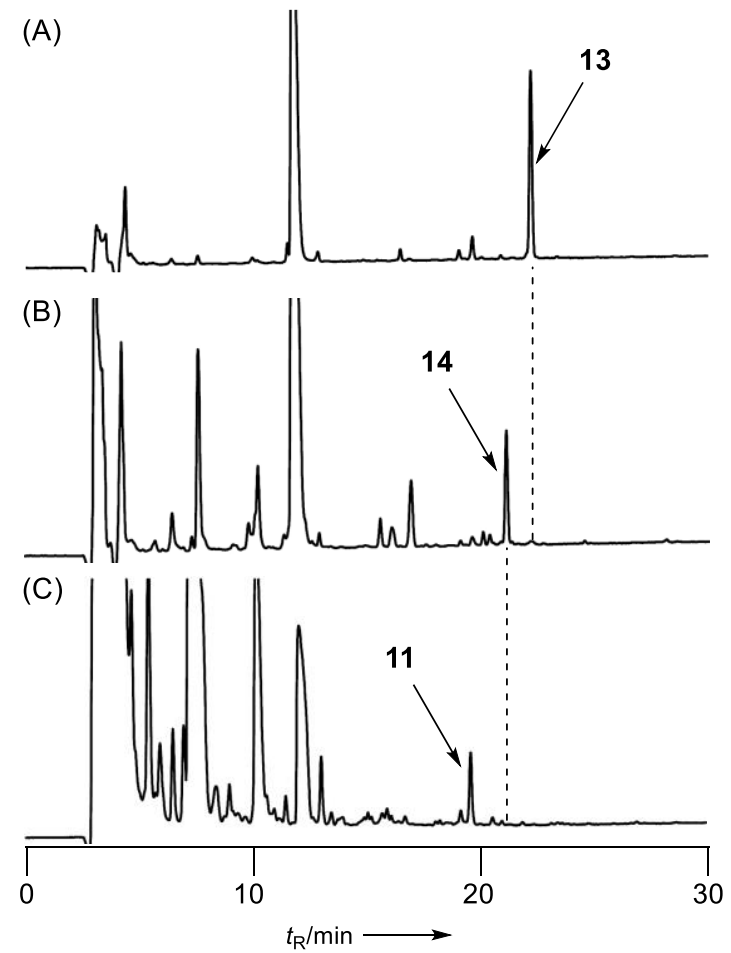

Figure S6. Analytical HPLC charts of crude reaction material. (A) 1st NCL: $t=4 \mathrm{~h}$; (B) 2nd NCL: $t$ $=7 \mathrm{~h}$; $(\mathrm{C})$ One-pot desulfurization: $t=6 \mathrm{~h}$. Analytical HPLC conditions: linear gradient of solvent $\mathrm{B}$ in solvent $\mathrm{A}, 5 \%$ to $35 \%$ over $30 \mathrm{~min}$.

H-LYRANACLYRANA-SEAlide-G-NH2 (13): Analytical HPLC condition, linear gradient of solvent $\mathrm{B}$ in solvent A, 5 to $35 \%$ over $30 \mathrm{~min}$, retention time $=22.2 \mathrm{~min}$, MS (ESI-TOF) $\mathrm{m} / \mathrm{z}$ calcd for $[\mathrm{M}+2 \mathrm{H}]^{2+} 867.43$, found 867.55 . 
H-LYRANACLYRANACSPGYS-NH2 (14): Analytical HPLC condition, linear gradient of solvent B in solvent A, 5 to $35 \%$ over $30 \mathrm{~min}$, retention time $=21.2 \mathrm{~min}$, MS (ESI-TOF) $\mathrm{m} / z$ calcd for $[\mathrm{M}+3 \mathrm{H}]^{3+}$ 698.00, found 698.05.

H- LYRANAALYRANAASPGYS- $\mathrm{NH}_{2}$ (11): Analytical HPLC condition, linear gradient of solvent B in solvent A, 5 to $35 \%$ over $30 \mathrm{~min}$, retention time $=19.5 \mathrm{~min}$, MS (ESI-TOF) $\mathrm{m} / \mathrm{z}$ calcd for $[\mathrm{M}+3 \mathrm{H}]^{3+}$ 676.69 , found 676.70 .

\section{One-pot/three-fragment $N C L$-desulfurization ( $C$-to-N protocol) using methoxyamine.}

A solution of N-terminal Thz SMDMAP thioester peptide $15(0.05 \mu \mathrm{mol})$ and N-terminal cysteinyl peptide $7(0.50 \mu \mathrm{mol})$ in $6 \mathrm{M} \mathrm{Gn} \cdot \mathrm{HCl}-0.2 \mathrm{M} \mathrm{Na}$ phosphate buffer $(\mathrm{pH} 6.9,50 \mu \mathrm{L}) \quad$ containing $5 \mathrm{mM}$ TCEP was stirred at $37^{\circ} \mathrm{C}$. After $3 \mathrm{~h}$ reaction (Figures S7(A)), the reaction mixture was treated with methoxyamine $(0.84 \mathrm{mg}, 0.01 \mu \mathrm{mol})$ at $\mathrm{pH} 4.2$ for $4 \mathrm{~h}$ (Figures $4(\mathrm{~A})$ and $\mathrm{S} 7(\mathrm{~B})$ ). Then, re-adjustment of $\mathrm{pH}$ of the mixture to 6.9 followed by the addition of peptide thioester $6 \mathrm{a}$ in $6 \mathrm{M} \mathrm{Gn} \cdot \mathrm{HCl}-0.2 \mathrm{M} \mathrm{Na}$ phosphate buffer (pH 6.9, $50 \mu \mathrm{L}$ ) containing $50 \mathrm{mM}$ TCEP and $10 \mathrm{mM}$ of $\mathbf{5} \cdot 2 \mathrm{HCl}$ initiated the $2 \mathrm{nd}$ NCL step to give the reaction containing fully ligated product 14 after $2 \mathrm{~h}$ reaction at $37^{\circ} \mathrm{C}$ (Figures 4(B) and S7(C)). Subsequent desulfurization by the addition of $600 \mathrm{mM}$ TCEP, $240 \mathrm{mM} \mathrm{VA-044}$ and $240 \mathrm{mM}$ glutathione in $0.2 \mathrm{M} \mathrm{Na}$ phosphate buffer $(50 \mu \mathrm{L})$ reached completion at $37{ }^{\circ} \mathrm{C}$ for $2 \mathrm{~h}$ (Figures 4(C) and S7(D)). Finally, to the mixture was added an equal volume of the quenching buffer containing $100 \mathrm{mM} \mathrm{Na}$ ascorbate in $6 \mathrm{M} \mathrm{Gn} \cdot \mathrm{HCl}$ to quench the reaction. Semi-preparative HPLC purification gave $\mathbf{1 1}$ in $41 \%$ isolated yield. 
(A)

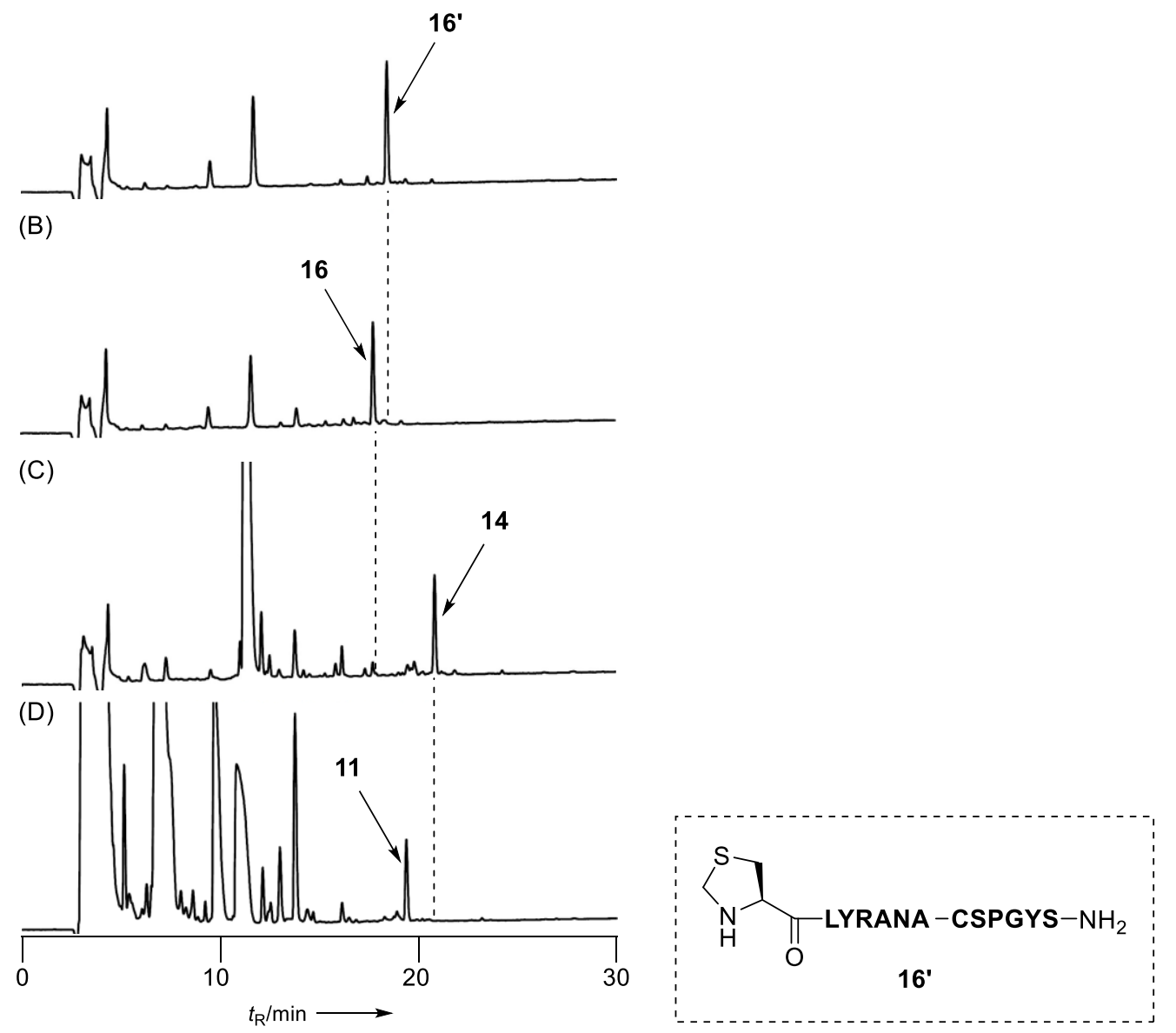

Figure S7. Analytical HPLC charts of crude reaction material. (A) 1st NCL: $t=3 \mathrm{~h}$; (B) Deprotection of Thz: $t=4 \mathrm{~h}$; (C) 2nd NCL: $t=2 \mathrm{~h}$; (D) One-pot desulfurization: $t=2 \mathrm{~h}$. Analytical HPLC conditions: linear gradient of solvent B in solvent A, 5\% to $35 \%$ over $30 \mathrm{~min}$.

H-ThzLYRANACSPGYS-NH2 (16'): Analytical HPLC condition, linear gradient of solvent $\mathrm{B}$ in solvent A, 5 to $35 \%$ over $30 \mathrm{~min}$, retention time $=19.4 \mathrm{~min}, \mathrm{MS}\left(\right.$ ESI-TOF) $\mathrm{m} / \mathrm{z}$ calcd for $[\mathrm{M}+2 \mathrm{H}]^{2+}$ 708.32, found 708.40.

H-CLYRANACSPGYS- $\mathrm{NH}_{2}$ (16): Analytical HPLC condition, linear gradient of solvent B in solvent A, 5 to $35 \%$ over $30 \mathrm{~min}$, retention time $=17.7 \mathrm{~min}$, MS $(\mathrm{ESI}-\mathrm{TOF}) \mathrm{m} / \mathrm{z}$ calcd for $[\mathrm{M}+2 \mathrm{H}]^{2+} 702.32$, found 702.30 . 


\section{One-pot/C-to-N directed NCLs-desulfurization using copper salt}

The first NCL of N-terminal Thz SMDMAP thioester peptide $15(0.50 \mu \mathrm{mol})$ with N-terminal cysteinyl peptide $7(0.50 \mu \mathrm{mol})$ in $6 \mathrm{M} \mathrm{Gn} \cdot \mathrm{HCl}-0.2 \mathrm{M} \mathrm{Na}$ phosphate buffer $(\mathrm{pH} 6.9,50 \mu \mathrm{L})$ containing $5 \mathrm{mM}$ TCEP at $37{ }^{\circ} \mathrm{C}$ for $3 \mathrm{~h}$ gave 1 st ligation product. To the reaction mixture was added $100 \mathrm{mM} \mathrm{CuSO}$ aq. ( $5 \mu \mathrm{L}, 10$ equiv. to peptide) to open the thiazolidine ring. Reaction at $37{ }^{\circ} \mathrm{C}$ for $5 \mathrm{~h}$ afforded the ring-opening product 16 (Figure $\mathrm{S} 8(\mathrm{~A})$ ). After re-adjustment of $\mathrm{pH}$ of the mixture to 6.9, peptide thioester 6a $(0.75 \mu \mathrm{mol})$ in $6 \mathrm{M} \mathrm{Gn} \cdot \mathrm{HCl}-0.2 \mathrm{M}$ HEPPS buffer $(\mathrm{pH} 6.9,50 \mu \mathrm{L})$ containing $50 \mathrm{mM}$ TCEP and $10 \mathrm{mM}$ of $\mathbf{5} \cdot 2 \mathrm{HCl}$ was added to the mixture. Attempted 2 nd ligation proceeded efficiently at $37^{\circ} \mathrm{C}$ for $2 \mathrm{~h}$ to yield the fully ligated product 14 (Figure S8(B)). However, one-pot/desulfurization by the addition of $600 \mathrm{mM}$ TCEP, $240 \mathrm{mM}$ VA-044 and $240 \mathrm{mM}$ glutathione in $0.2 \mathrm{M}$ Na phosphate buffer $(50 \mu \mathrm{L})$ required long reaction time not to go to completion as shown in Figure S8(C). Additional additives (EDTA, DTT or DTC) to the desulfurization mixture did not improve the reaction (Figure S9(A-C)).

(A)

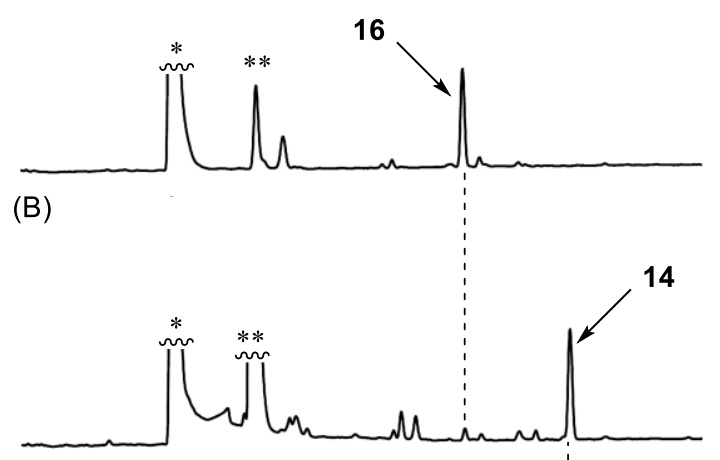

(C)

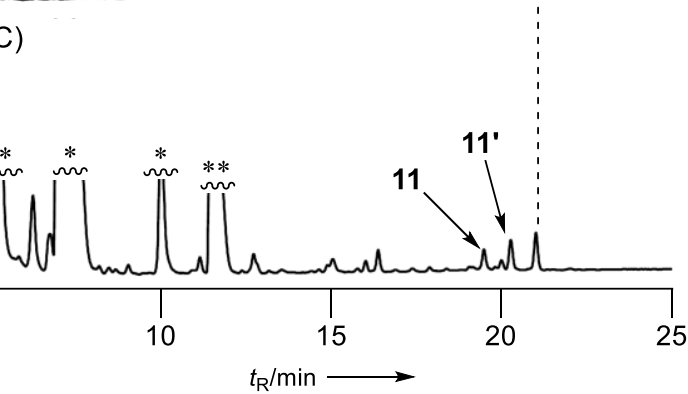

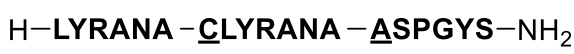

or

H-LYRANA - ALYRANA - CSPGYS- $\mathrm{NH}_{2}$

$1^{\prime}$

Figure S8. Analytical HPLC charts of crude reaction material. (A) Deprotection of Thz: $t=5 \mathrm{~h}$; (B) 2nd NCL: $t=2 \mathrm{~h}$; (C) Desulfurization: $t=15 \mathrm{~h}$. Analytical HPLC conditions: linear gradient of solvent $\mathrm{B}$ in solvent $\mathrm{A}, 5 \%$ to $35 \%$ over $30 \mathrm{~min}$. *Non-peptide impurity; ** SMDMAP.

H- LYRANAA(C)LYRANAA(C)SPGYS-NH2 (11'): Analytical HPLC condition, linear gradient of solvent B in solvent A, 5 to $35 \%$ over $30 \mathrm{~min}$, retention time $=20.4 \mathrm{~min}$, MS (ESI-TOF) $\mathrm{m} / \mathrm{z}$ calcd for $[\mathrm{M}+3 \mathrm{H}]^{3+} 687.35$, found 687.40 . 
Examination of desulfurization reaction in the presence of copper salts

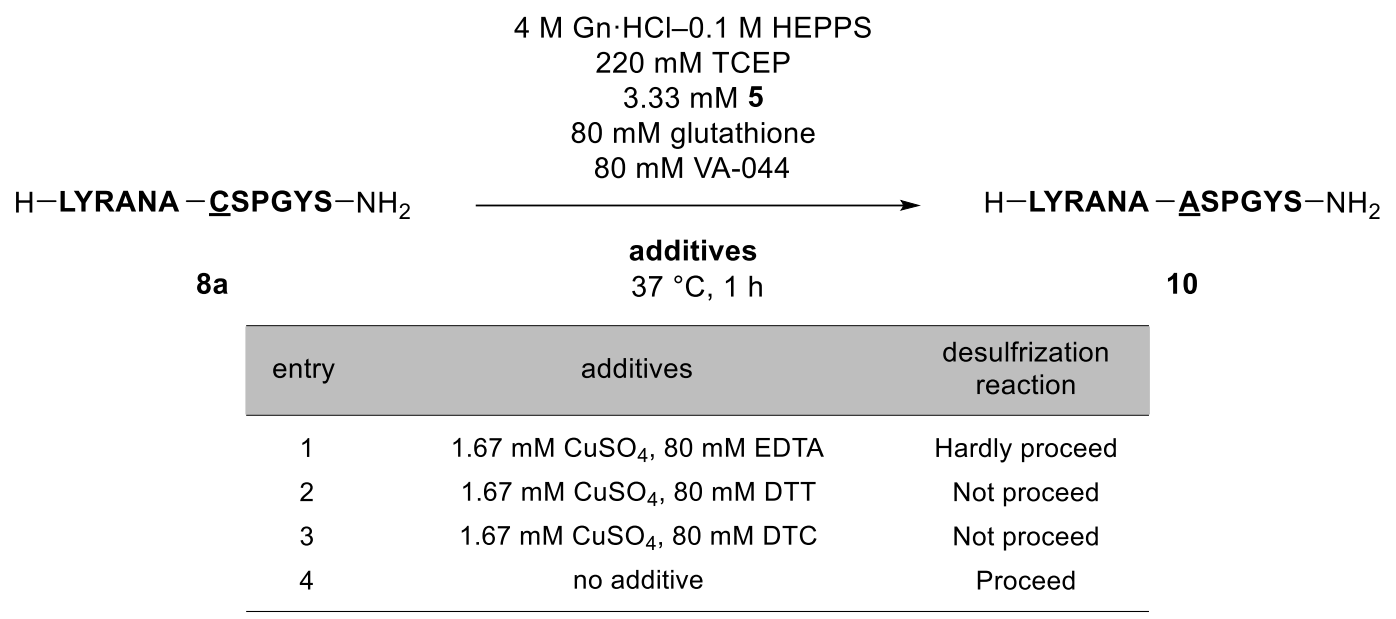

(A)

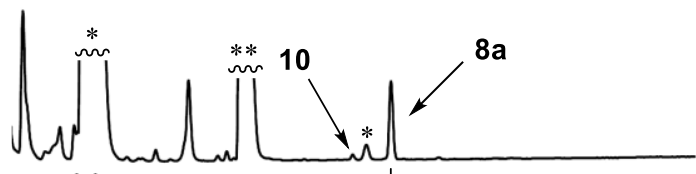

(B)

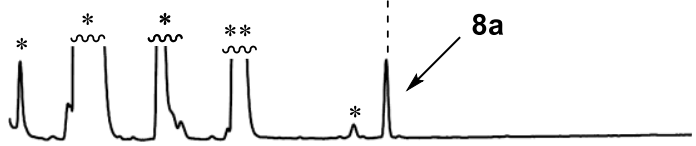

(C)

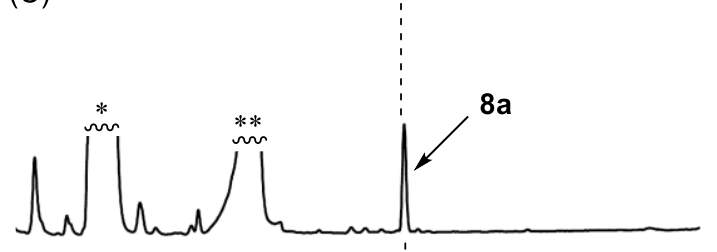

(D)

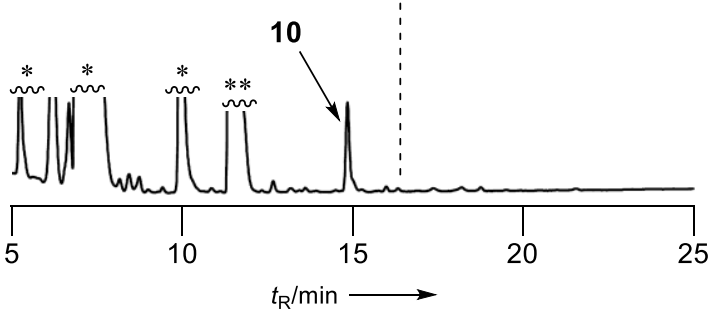

Figure S9. Analytical HPLC charts of crude reaction material. (A) Entry 1 (EDTA); (B) Entry 2 (DTT); (C) Entry 3 (DTC); (D) Entry 4 (no additive). Analytical HPLC conditions: linear gradient of solvent $\mathrm{B}$ in solvent $\mathrm{A}, 5 \%$ to $35 \%$ over $30 \mathrm{~min}$. *Non-peptide impurity; ** SMDMAP. 
Optimization of reaction conditions for SMDMAP-mediated lactam formation and synthesis of lactam peptide $1 \mathbf{8}^{20)}$.

\section{Lactam-type peptide synthesis.}

Substrate linear thioester peptide $17(0.5 \mathrm{mM})$ was subjected to the reactions (Table S1, entries 1-7) in $\mathrm{NMP} / \mathrm{H}_{2} \mathrm{O}(4: 1, \mathrm{v} / \mathrm{v})$ in the presence of 5 and other additional additives at $37{ }^{\circ} \mathrm{C}$ for $3 \mathrm{~h}$ and the progress of attempted reactions was monitored by HPLC analyses. Results are summarized in Table S1.

Table S1. Optimization of reaction conditions for synthesis of lactam peptide $\mathbf{1 8 .}$

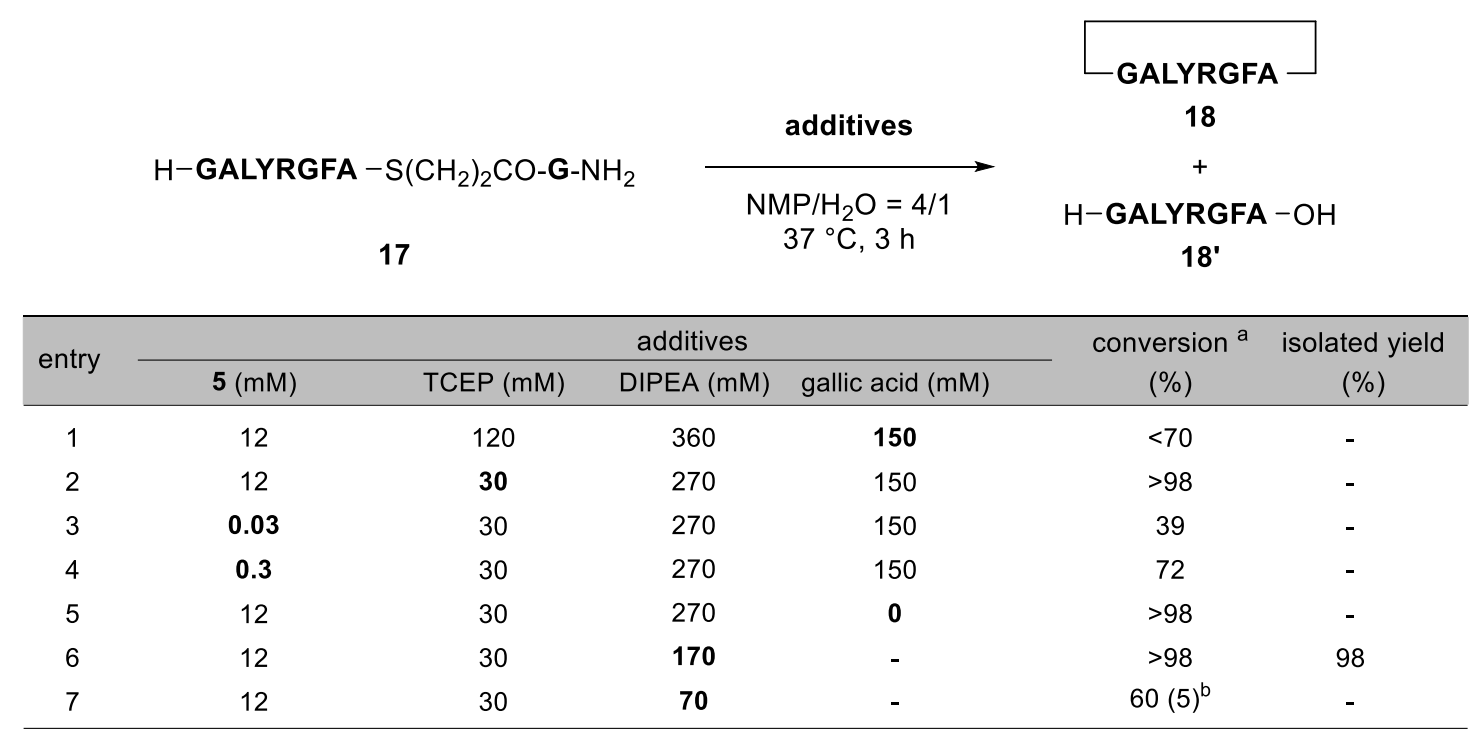

aDetermined by HPLC analysis (detection at $220 \mathrm{~nm}$ ) using the following equation. (conversion = integ. (18 or $\mathbf{1 8}^{\prime}$ )/ integ. (all peptide peaks)), ${ }^{\text {b}}$ Conversion yield of hydrolyzed peptide $\mathbf{1 8}$ '.

Cyclo(-GALYRGFA-) (18): Analytical HPLC conditions, linear gradient of solvent B in solvent A, 5 to $45 \%$ over $30 \mathrm{~min}$, retention time $=20.7 \mathrm{~min}$, LCMS (ESI-TOF) $\mathrm{m} / \mathrm{z}$ calcd for $[\mathrm{M}+\mathrm{H}]^{+} 836.44$, found 836.53 .

H-GALYRGFA-OH (18'): Analytical HPLC conditions, linear gradient of solvent B in solvent A, 5 to $45 \%$ over $30 \mathrm{~min}$, retention time $=17.5 \mathrm{~min}$, LCMS (ESI-TOF) $\mathrm{m} / \mathrm{z}$ calcd for $[\mathrm{M}+\mathrm{H}]^{+} 854.45$, found 854.20 . 
Substrate versatility in lactam formation using SMDMAP

In addition to 17, other linear thioester peptides possessing different chain length or C-terminal amino acids were subjected to the cyclization reaction under the optimized conditions (Table S1, entry 6). Obtained results are summarized in Table S2. Additionally, epimerization during cyclization was evaluated using peptides 17 and S1 (Table S2, entries 1 and 2, Figure S10).

Table S2. Applicability of SMDMAP-mediated cyclization to the synthesis of various lactam peptides.

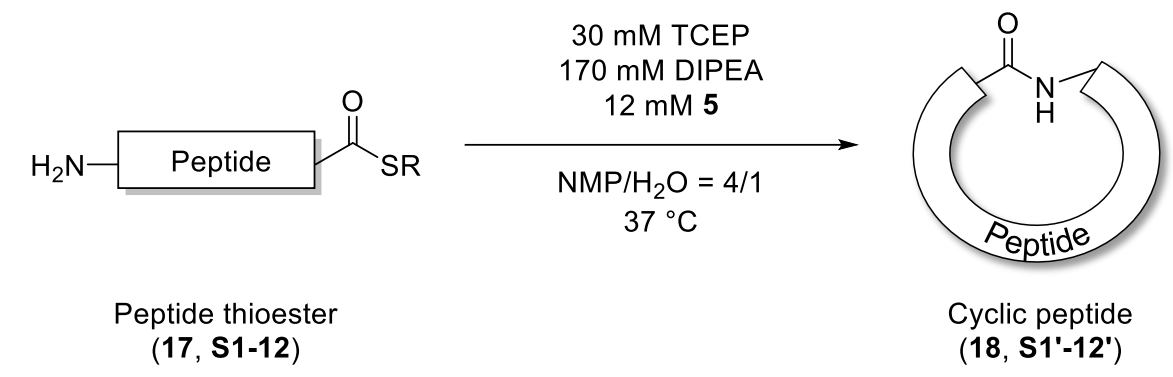

\begin{tabular}{|c|c|c|c|c|c|}
\hline entry & peptide & sequence & time $(h)$ & conversion $^{\mathrm{a}}(\%)$ & epimerization (\%) \\
\hline 1 & 17 & H-GALYRGFA-SR ${ }^{1}$ & 3 & $>95$ & n.d. \\
\hline 2 & s1 & H-GALYRGFS-SR ${ }^{1}$ & 3 & $>95$ & 3.2 \\
\hline 3 & s2 & H-GALYRGFV-SR ${ }^{1}$ & 12 & 65 & - \\
\hline 4 & s3 & H-FALYRGFA -SR ${ }^{1}$ & 12 & 76 & - \\
\hline 5 & s4 & H-DALYRGFA-SR ${ }^{1}$ & 3 & $>95$ & - \\
\hline 6 & S5 & H-NALYRGFA-SR ${ }^{1}$ & 3 & 84 & - \\
\hline 7 & s6 & H-GALYRDFA-SR ${ }^{1}$ & 3 & $>95$ & - \\
\hline 8 & s7 & H-GLYRA-SR ${ }^{2}$ & 6 & 87 & - \\
\hline 9 & s8 & H-GGLYRA-SR ${ }^{2}$ & 6 & 87 & - \\
\hline 10 & s9 & H-GNGLYRA-SR ${ }^{2}$ & 6 & 89 & - \\
\hline 11 & s10 & H-GANGLYRA-SR ${ }^{2}$ & 6 & 91 & - \\
\hline 12 & S11 & H-GRANGLYRA-SR ${ }^{2}$ & 6 & 80 & - \\
\hline 13 & S12 & H-GLRANGLYRA-SR ${ }^{2}$ & 6 & 78 & - \\
\hline
\end{tabular}

${ }^{a}$ Conversion is determined by HPLC analysis (detection at $220 \mathrm{~nm}$ ) using the follow-ing equation, Conversion $=$ integ. $($ Cyclic peptide $) /$ integ. $($ All peptide peaks $)$. n.d.: not detected; $\mathrm{R}^{1}:\left(\mathrm{CH}_{2}\right)_{2} \mathrm{CO}-$ Gly- $\mathrm{NH}_{2}, \mathrm{R}^{2}:\left(\mathrm{CH}_{2}\right){ }_{2} \mathrm{CO}_{2} \mathrm{H}$. 
Cyclo(-GALYRGFS-) (S1'): Analytical HPLC conditions, linear gradient of solvent B in solvent A, 5 to $45 \%$ over $30 \mathrm{~min}$, retention time $=19.0 \mathrm{~min}$. LCMS (ESI-TOF) $\mathrm{m} / z$ calcd for $[\mathrm{M}+\mathrm{H}]^{+} 864.48$, found 864.32 .

Cyclo(-GALYRGFV-) (S2'): Analytical HPLC conditions, linear gradient of solvent B in solvent A, 5 to $45 \%$ over $30 \mathrm{~min}$, retention time $=25.9 \mathrm{~min}$. LCMS (ESI-TOF) $\mathrm{m} / \mathrm{z}$ calcd for $[\mathrm{M}+\mathrm{H}]^{+} 852.44$, found 852.27 .

Cyclo(-FALYRGFA-) (S3'): Analytical HPLC conditions, linear gradient of solvent B in solvent A, 5 to $45 \%$ over $30 \mathrm{~min}$, retention time $=28.9 \mathrm{~min}$. LCMS (ESI-TOF) $\mathrm{m} / z$ calcd for $[\mathrm{M}+\mathrm{H}]^{+} 926.49$, found 926.25 .

Cyclo(-DALYRGFA-) (S4'): Analytical HPLC conditions, linear gradient of solvent B in solvent A, 5 to $45 \%$ over $30 \mathrm{~min}$, retention time $=21.1 \mathrm{~min}$. LCMS (ESI-TOF) $\mathrm{m} / z$ calcd for $[\mathrm{M}+\mathrm{H}]^{+} 894.45$, found 894.55 .

Cyclo(-NALYRGFV-) (S5'): Analytical HPLC conditions, linear gradient of solvent B in solvent A, 5 to $45 \%$ over $30 \mathrm{~min}$, retention time $=20.9 \mathrm{~min}$. LCMS (ESI-TOF) $\mathrm{m} / \mathrm{z}$ calcd for $[\mathrm{M}+\mathrm{H}]^{+} 893.24$, found 893.25 .

Cyclo(-GALYRDFA-) ( $\mathbf{S 6}^{\text {'}}$ ): Analytical HPLC conditions, linear gradient of solvent B in solvent A, 5 to $45 \%$ over $30 \mathrm{~min}$, retention time $=21.2 \mathrm{~min}$. LCMS (ESI-TOF) $\mathrm{m} / \mathrm{z}$ calcd for $[\mathrm{M}+\mathrm{H}]^{+} 894.45$, found 894.55 .

Cyclo(-GLYRA-) (S7'): Analytical HPLC conditions, linear gradient of solvent B in solvent A, 5 to $45 \%$ over $30 \mathrm{~min}$, retention time $=16.4 \mathrm{~min}$. LCMS (ESI-TOF) $\mathrm{m} / z$ calcd for $[\mathrm{M}+\mathrm{H}]^{+} 561.32$, found 561.34 .

Cyclo(-GGLYRA-) (S8'): Analytical HPLC conditions, linear gradient of solvent B in solvent A, 5 to $45 \%$ over $30 \mathrm{~min}$, retention time $=13.3 \mathrm{~min}$. LCMS (ESI-TOF) $\mathrm{m} / \mathrm{z}$ calcd for $[\mathrm{M}+\mathrm{H}]^{+} 618.33$, found 618.33 .

Cyclo(-GNGLYRA-) (S9'): Analytical HPLC conditions, linear gradient of solvent B in solvent A, 5 to $45 \%$ over $30 \mathrm{~min}$, retention time $=13.2 \mathrm{~min}$. LCMS (ESI-TOF) $\mathrm{m} / z$ calcd for $[\mathrm{M}+\mathrm{H}]^{+} 732.38$, found 732.29 .

Cyclo(-GANGLYRA-) (S10'): Analytical HPLC conditions, linear gradient of solvent B in solvent A, 5 to $45 \%$ over $30 \mathrm{~min}$, retention time $=13.2 \mathrm{~min}$. LCMS (ESI-TOF) $\mathrm{m} / z$ calcd for $[\mathrm{M}+\mathrm{H}]^{+} 803.42$, found 803.41 .

Cyclo(-GRANGLYRA-) (S11'): Analytical HPLC conditions, linear gradient of solvent B in solvent A, 5 to $45 \%$ over $30 \mathrm{~min}$, retention time $=12.3 \mathrm{~min}$. LCMS (ESI-TOF) $\mathrm{m} / \mathrm{z}$ calcd for $[\mathrm{M}+2 \mathrm{H}]^{2+} 480.26$, found 480.25 .

Cyclo(-GLRANGLYRA-) (S12'): Analytical HPLC conditions, linear gradient of solvent B in solvent A, 5 to $45 \%$ over $30 \mathrm{~min}$, retention time $=16.2 \mathrm{~min}$. LCMS (ESI-TOF) $\mathrm{m} / \mathrm{z}$ calcd for $[\mathrm{M}+2 \mathrm{H}]^{2+} 536.80$, found 536.86 . 
Verification of epimerization of C-terminal chiral amino acids during lactam formation

\section{Preparation of peptide S19 and S20.}

Lactam formation of $\mathbf{S 1 5}$ or $\mathbf{S 1 6}$ was performed in NMP/ $\mathrm{H}_{2} \mathrm{O}$ (4/1 v/v), $170 \mathrm{mM}$ DIPEA, $30 \mathrm{mM}$ TCEP and $12 \mathrm{mM} 5 \cdot 2 \mathrm{HCl}$ at $50{ }^{\circ} \mathrm{C}$. After incubation for $12 \mathrm{~h}$, the crude product was purified by semi-preparative HPLC to give the ligated product $\mathbf{S 1 9}$ or $\mathbf{S 2 0}$.

(A)

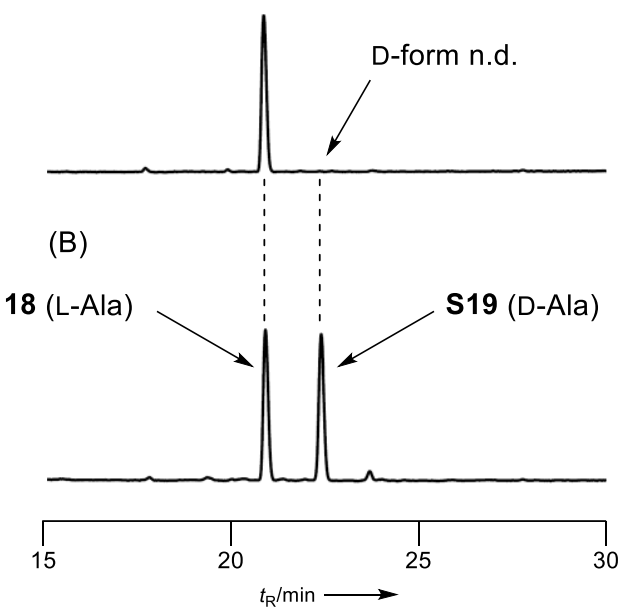

(C)

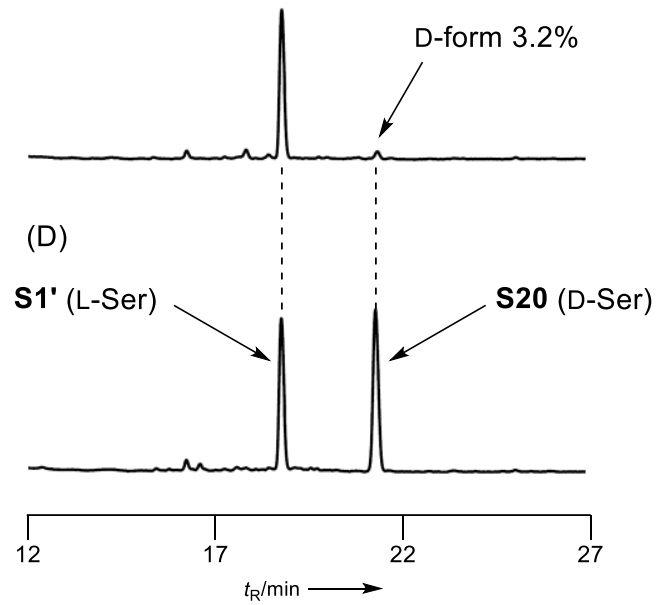

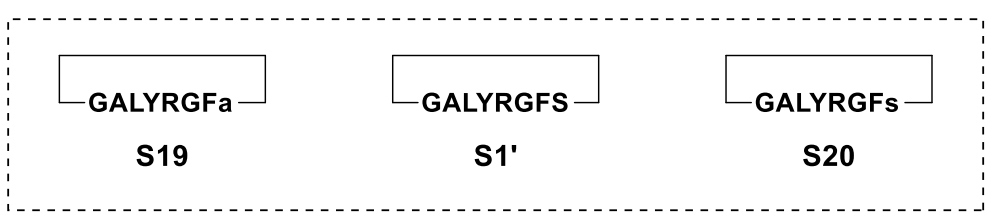

Figure S10. Verification of epimerization of C-terminal chiral amino acids during lactam formation. (A) Crude reaction material (Substrate 17), $t=3 \mathrm{~h}$; (B) Co-injection 18 with S19; (C) Crude reaction material (substrate S1), $t=3$ h; (D) Co-injection S1' with S20; n.d. means not detected. Analytical HPLC conditions: linear gradient of solvent B in solvent A, 5 to $45 \%$ over $30 \mathrm{~min}$. *Non-peptide impurity.

Cyclo(-GALYRGFa-) (S19): Analytical HPLC conditions, linear gradient of solvent B in solvent A, 5 to $45 \%$ over $30 \mathrm{~min}$, retention time $=22.6 \mathrm{~min}$, LCMS (ESI-TOF) $\mathrm{m} / \mathrm{z}$ calcd for $[\mathrm{M}+\mathrm{H}]^{+} 836.44$, found 836.50 .

Cyclo(-GALYRGFs-) (S20): Analytical HPLC conditions, linear gradient of solvent B in solvent A, 5 to $45 \%$ over $30 \mathrm{~min}$, retention time $=21.5 \mathrm{~min}$, LCMS (ESI-TOF) $\mathrm{m} / \mathrm{z}$ calcd for $[\mathrm{M}+\mathrm{H}]^{+} 852.43$, found 852.24 . 
Comparative study of the additives in lactam formation

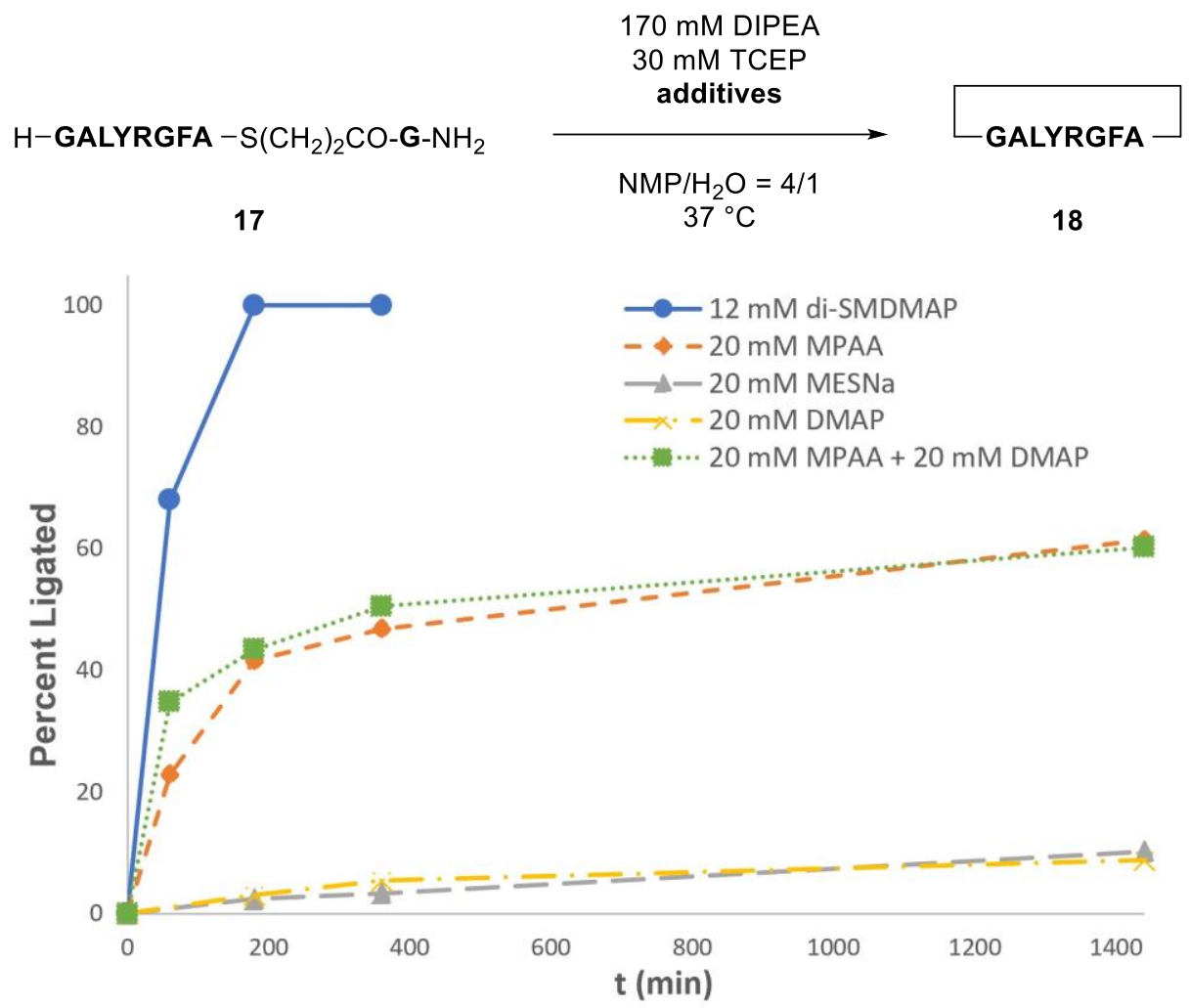

Figure S11. Kinetic study for lactam formation reaction using various additives. Percentages of ligation were determined by HPLC analyses with UV detection at $220 \mathrm{~nm}$ and calculated using the following equation (percent ligated $=100 \mathrm{x}$ (integration (integ.) 18 / (integ. $17+$ integ. 18)). 
Comparative study of the additives in lactone formation

\section{Synthetic procedure of lactone-type peptide.}

Peptide alkylthioester $19(0.05 \mu \mathrm{mol})$ was dissolved in NMP $(100 \mu \mathrm{L})$ containing $80 \mathrm{mM}$ DIPEA, 40 $\mathrm{mM}$ TCEP and $24 \mathrm{mM}$ of $\mathbf{5} \cdot 2 \mathrm{HCl}$, the mixture was stirred at $50^{\circ} \mathrm{C}$ for $3 \mathrm{~h}$ to afford the desired lactam peptide 20. HPLC purification of the mixture diluted twice with $6 \mathrm{M} \mathrm{Gn} \cdot \mathrm{HCl}$ solution gave purified 20 in $86 \%$ isolated yield.

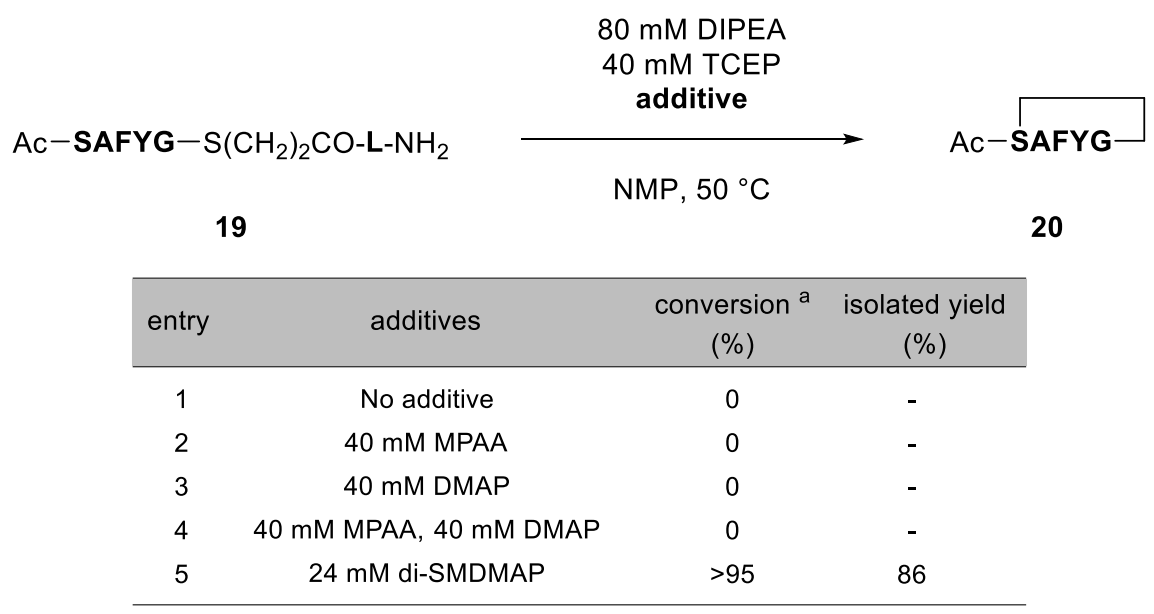

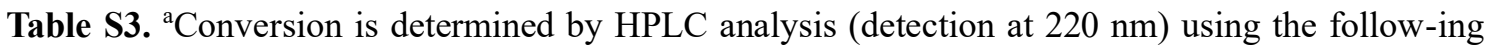
equation, Conversion $=$ integ.(20) $/$ integ.(All peptide peaks).

Cyclo(-AcSAFYG-) (20): Analytical HPLC conditions, linear gradient of solvent B in solvent A, 10 to $40 \%$ over $30 \mathrm{~min}$, retention time $=21.1 \mathrm{~min}$, LCMS $\left(\right.$ ESI-TOF) $\mathrm{m} / z$ calcd for $[\mathrm{M}+\mathrm{H}]^{+} 568.24$, found 568.25 . 


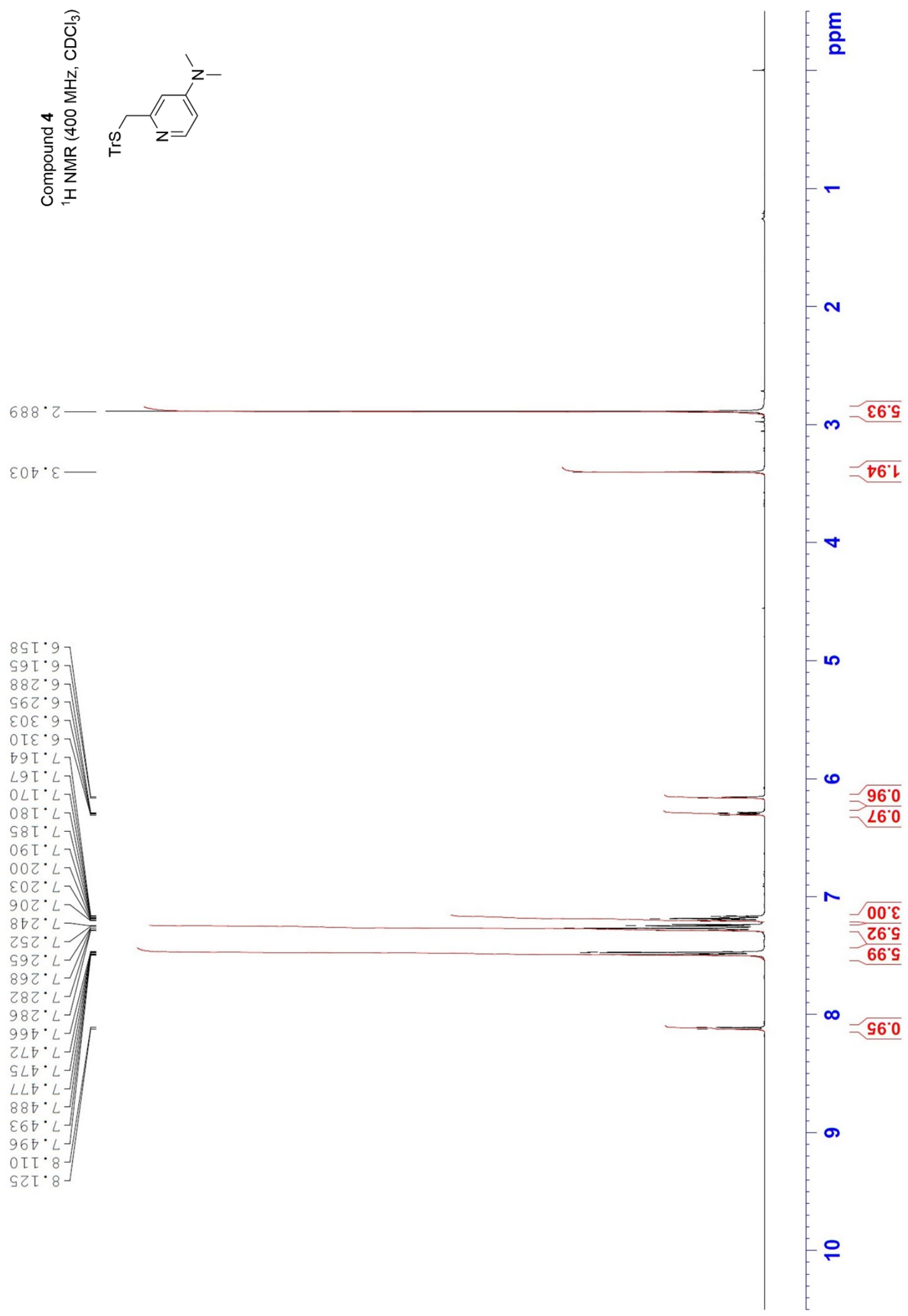



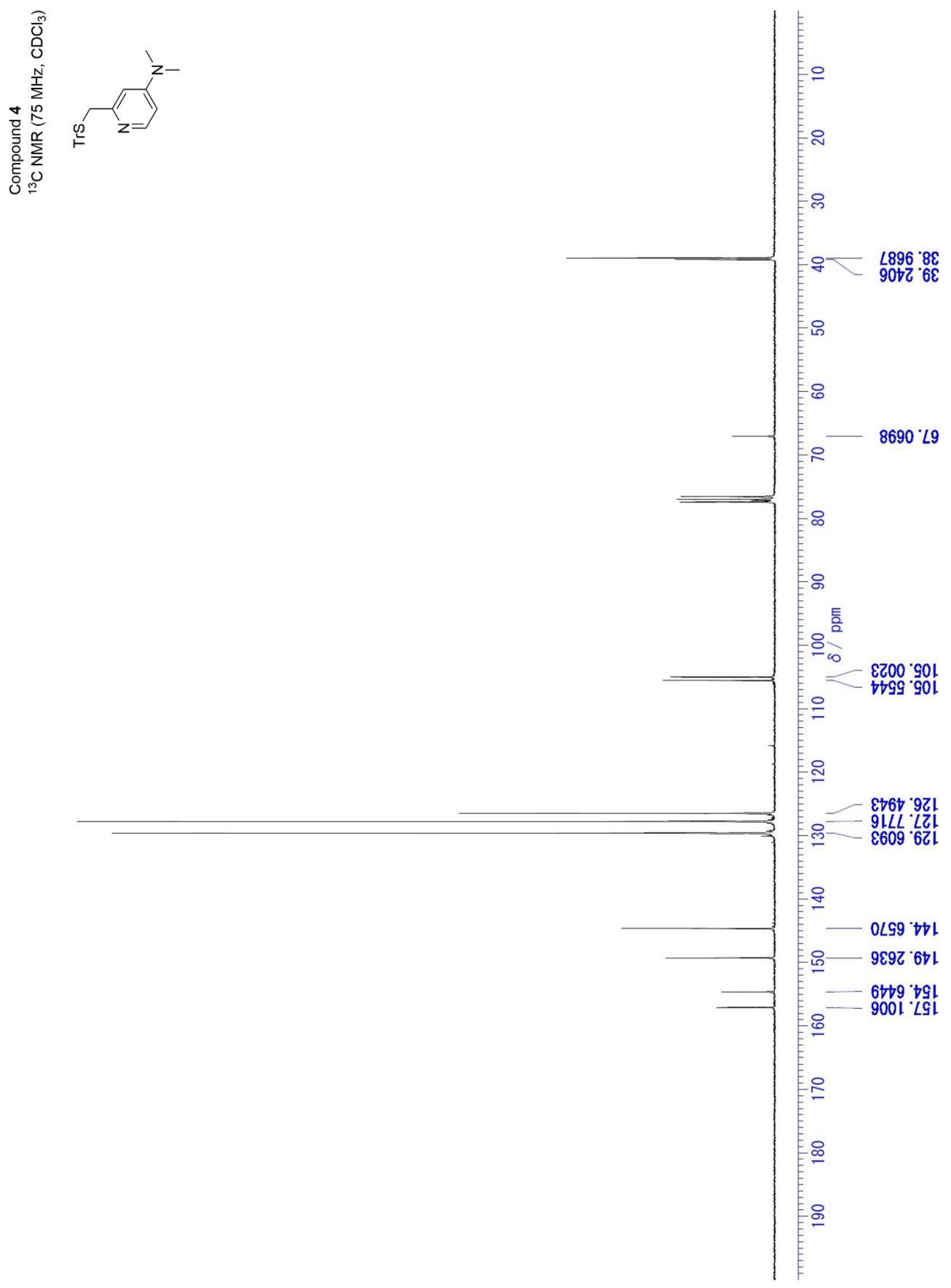


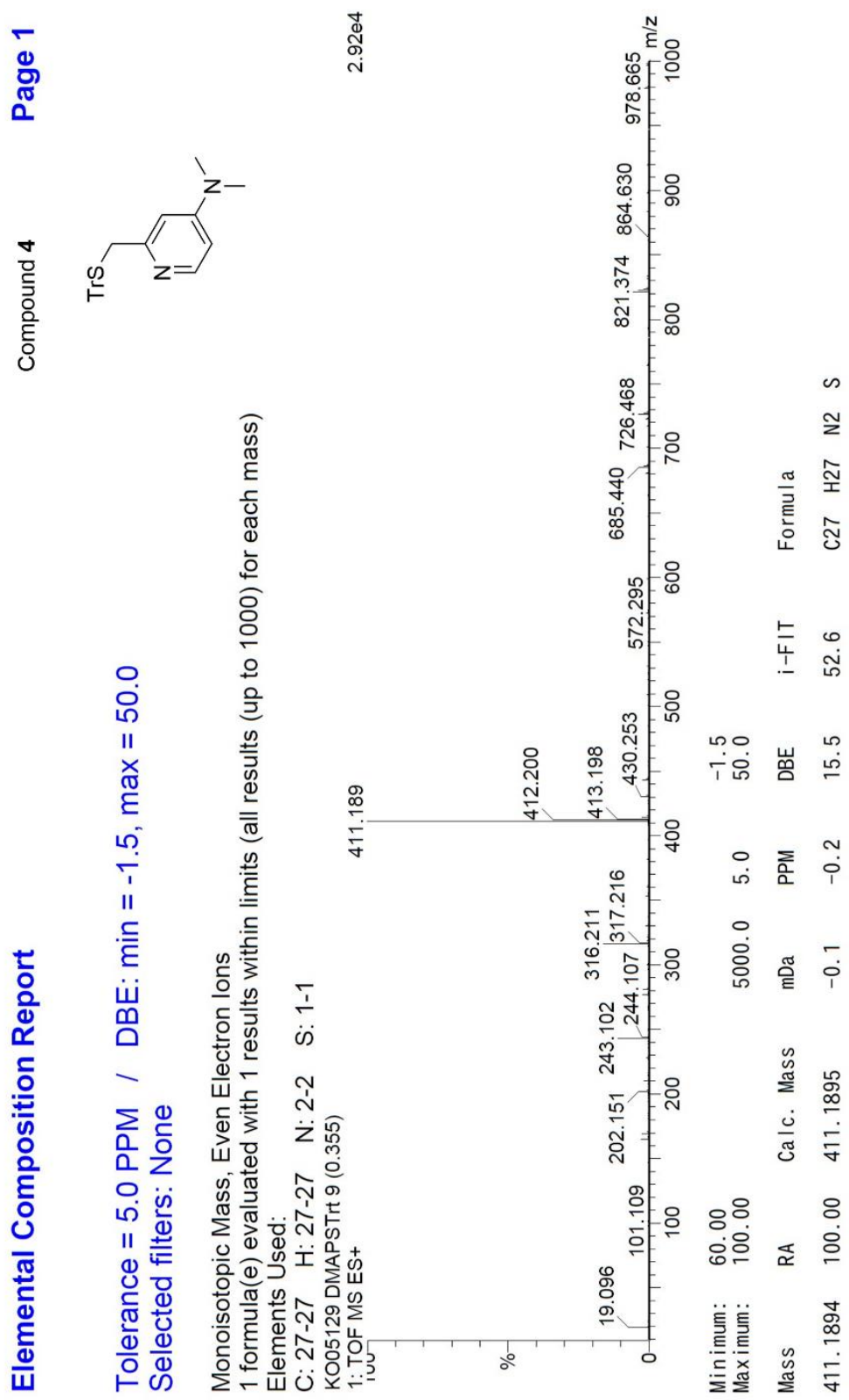




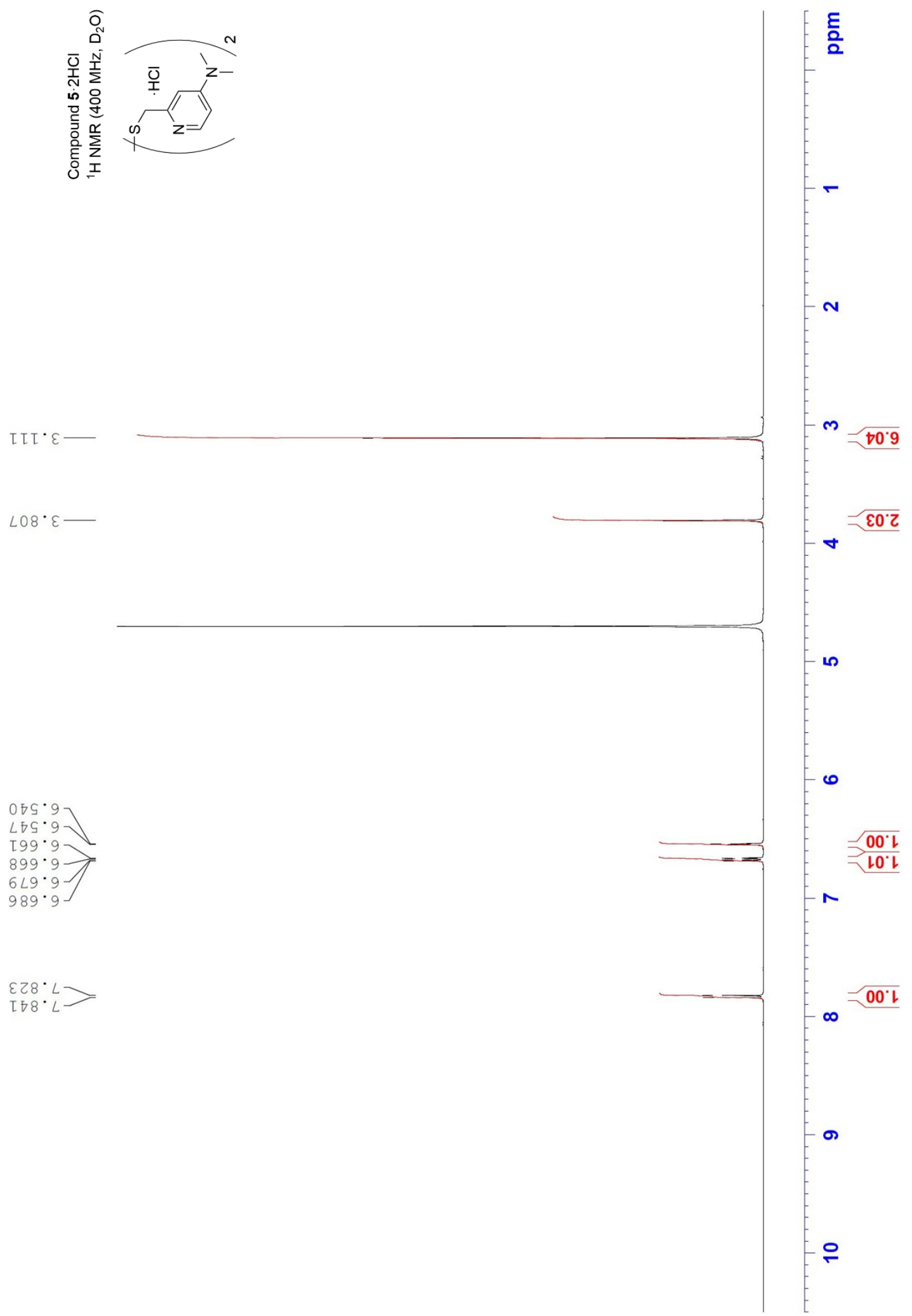



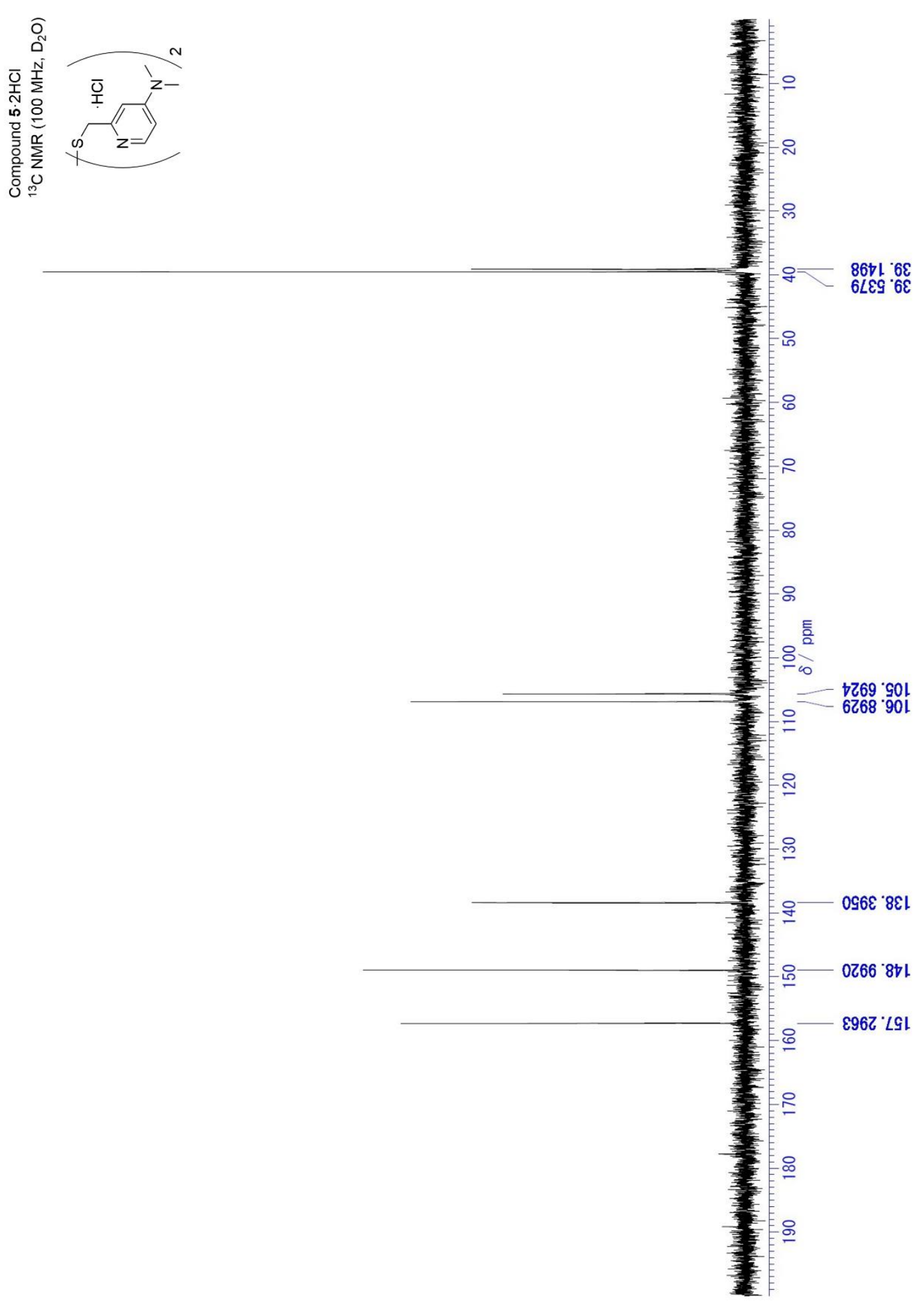


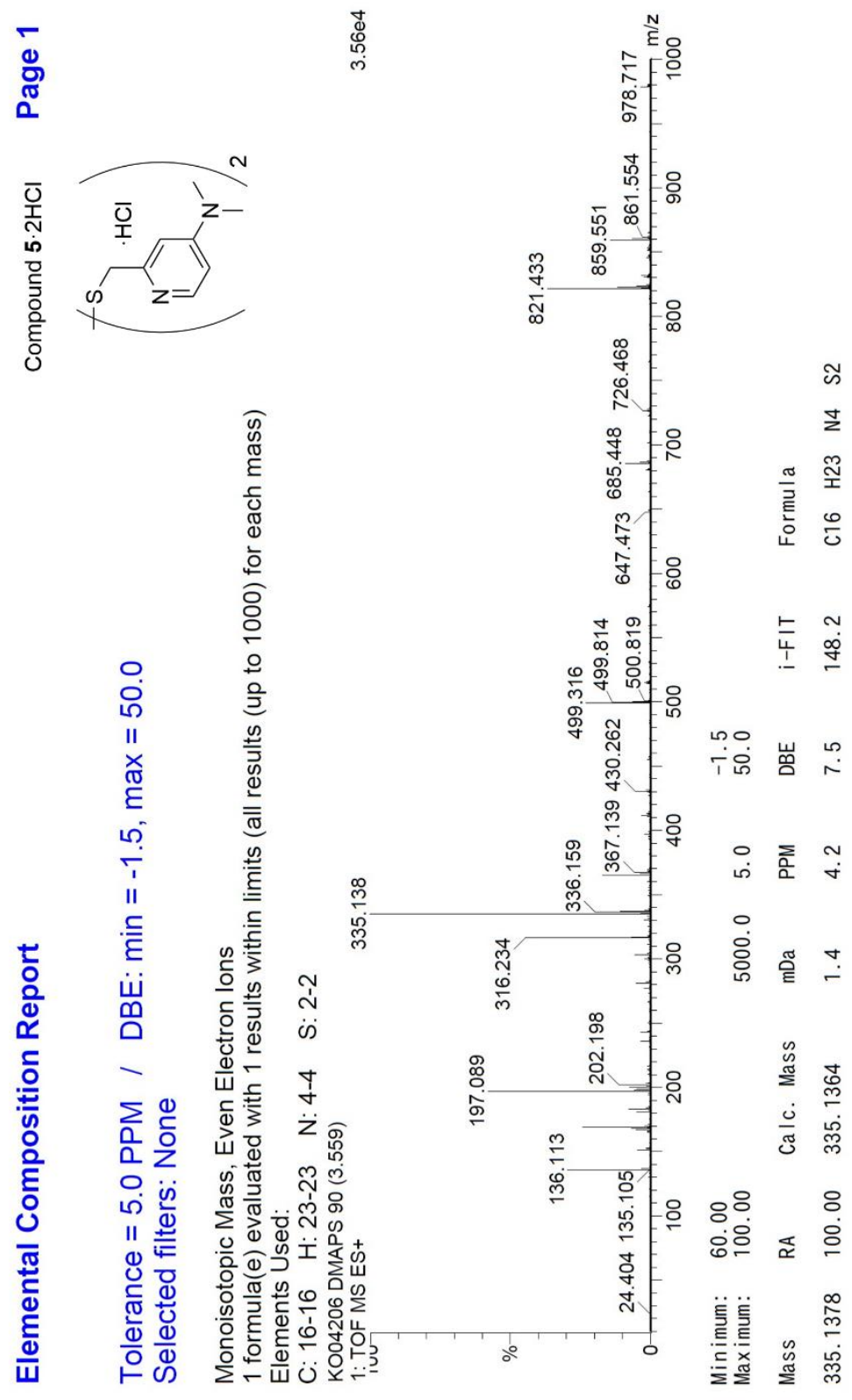




\section{Reference}

S1) (a) Fang, G.-M.; Li, Y.-M.; Shen, F.; Huang, Y.-C.; Li, J.-B.; Lin, Y.; Cui, H.-K. and Liu, L. Angew. Chem., Int. Ed., 2011, 50, 7645-7649. (b) Zheng, J.-S.; Tang, S.; Qi, Y.-K.; Wang, Z.-P. and Liu, L. Nat. Protoc., 2013, 8, 2483-2495. (c) Zheng, J.-S.; Tang, S.; Huang, Y.-C. and Liu, L. Acc. Chem. Res., 2013, 46, 2475-2484. (d) Sato, K.; Tanaka, S.; Yamamoto, K.; Tashiro, Y.; Narumi, T.; Mase, N. Chem. Commun. 2018, 54, 9127-9130.

S2) (a) Tsuda, S.; Shigenaga, A.; Bando, K.; Otaka, A. Org. Lett. 2009, 11, 823-826. (b) Sato, K.; Shigenaga, A.; Tsuji, K.; Tsuda, S.; Sumikawa, Y.; Sakamoto, K.; Otaka, A. ChemBioChem 2011, 12, 1840-1844. (c) Otaka, A.; Sato, K.; Ding, H.; Shigenaga, A. Chem. Rec. 2012, 12, 479-490. 